\title{
The Temple and Its Surroundings on Fabrika Hill, Paphos Preliminary Results of the French-Polish Excavations (2018-2019)
}

\author{
Claire Balandier, Jolanta MŁynarczyK
}

\begin{abstract}
The field research conducted in Paphos in the framework of a joint project of the Université d'Avignon and the University of Warsaw focuses on the southern part of Fabrika hill with the aim to understand its role in the urban life of ancient Nea Paphos. Two seasons of the fieldwork (2018-2019) yielded evidence for the arrangement and chronology of a temple site of the Hellenistic and early Roman period. A preliminary exploration of underground chambers strongly suggests that they may have been a part of the same sacred area as the temple. Moreover, several burials as well as some walls and floors testify to the use of the site during the Byzantine and Medieval period.
\end{abstract}

Keywords: Hellenistic-Roman period Cyprus, Nea Paphos, Fabrika hill, temple, underground chambers, Byzantine burials, Medieval period

Claire Balandier, Department of History, Avignon Université / UMR 8210 AnHiMA, Avignon; claire.balandier@univ-avignon.fr; (1) 000-0001-6919-1042

Jolanta Młynarczyk, Faculty of Archaeology, University of Warsaw, Warsaw; susyam@wp.pl, jolantamlynarczyk@uw.edu.pl; (D) 0000-0003-3473-104X

Since 2008, the Mission archéologique française à Paphos (MafaP), founded and lead by Claire Balandier (University of Avignon) has been conducting archaeological research in Paphos on Fabrika hill under the auspices of the Department of Antiquities of Cyprus. ${ }^{1}$ In antiquity, this rocky hillock constituting the north-eastern limits of the ancient city was an important part of Nea Paphos; in the modern record, however, it appeared relatively late. ${ }^{2}$ During ten years of fieldworks, the French team inventoried ancient remains on the hill and conducted excavations in three main areas, uncovering a Roman residential building (north

\footnotetext{
${ }^{1}$ For the bibliography of the research, see: Balandier 2015: 162, n. 3; for schematic plan of Fabrika hill, see Fig. 1 therein.

${ }^{2}$ For the mentions of Fabrika by nineteenth century travelers and early twentieth century researchers, see: Młynarczyk 2020: 60.
} 
sector), a part of the eastern rampart of the Hellenistic city wall (north-east sector), and an underground tunnel supplying a large Roman cistern with water (south-east sector). In 2017, co-operation was launched between the University of Avignon and the University of Warsaw with the aim of examining the southern part of the hill where a temple site was identified; according to the system adapted by the French mission, the area under investigation is a part of Chantier B. This paper is an extended and more detailed, as well as more abundantly illustrated, version of already published preliminary presentation of results of the excavations conducted there in May-June of 2018 and 2019. ${ }^{3}$

\section{HISTORY OF THE RESEARCH ON THE SOUTHERN PART OF FABRIKA HILL}

One of the features inventoried by the French team at the beginning of their work in 2008 on Fabrika was a rock-cut substructure of a building, interpreted as a temple platform by Wiktor A. Daszewski and Jolanta Młynarczyk, and first published on a sketchy plan in 1978. ${ }^{4}$ It is situated at the top of the hill, at its southern edge, right to the north-west of the early Hellenistic theatre. ${ }^{5}$ In 1987 a partial cleaning of the temple platform was undertaken by Günter Grimm from the University of Trier during a single season of excavations on the south of Fabrika hill. ${ }^{6}$ In 2015, Balandier re-cleaned the naos with the help of the staff of the Paphos District Museum, removing bushes from its western end, and gave a detailed description of its outline. ${ }^{7}$ In 2017 a new project of the fieldwork was undertaken within the framework of co-operation between the University of Avignon and the University of Warsaw. Two seasons of the excavations (2018-2019) focused on the temple platform, whose complete plan was finally accomplished, but at the same time the exploration was extended to its surroundings in order to understand the historical development of the area. ${ }^{8}$

3 See: Młynarczyk 2020 (originally a conference paper). The present paper is also differently profiled than the previous publication. While Młynarczyk 2020 was aimed at presenting the author's own hypotheses regarding the sacred area of Fabrika against first excavation results, in the present paper the authors wish to give a detailed account of the fieldwork in order to provide a sound base for further archaeological research.

4 Daszewski 1978: 181; Młynarczyk 1985: 286-292; 1990: 217-220 and Fig. 31 (the plan drawn by K. Kamiński, repeated by Wright 1992: Fig. 123, with mistaken sketch reconstruction of the temple building). See also: Młynarczyk 2015: 84.

${ }^{5}$ On the theatre excavated by the University of Sydney, see: Barker 2016: 94-95; for full bibliography, see website: PaphosTheatre.

${ }^{6}$ Unfortunately, no plan was published then, just a concise communication was given in the Annual Report of the Department of Antiquities of Cyprus and in the Bulletin de correspondence hellénique; see: Karageorghis 1988: 835-836. The artefacts from the German excavations kept at the Paphos Museum are mostly Medieval with very few Hellenistic sherds and a fragment of a limestone basin.

7 Balandier 2015: 163-165. A sketch plan, produced on that occasion, has not been published. A first Geographical Information Survey was made in 2015 by a team led by Charalampos Christakis, from the Department of Topography of the Ministry of Public Works of Cyprus.

${ }^{8}$ Fieldworks were led by Balandier and Młynarczyk, with the collaboration of Monika Rekowska and Mariusz Burdajewicz from the University of Warsaw, and Eric Chabert-Cuenca from the University of Avignon as well as students from both universities and British volunteers. Wiesław Małkowski was in charge of the GIS survey. Christopher Papadopoulos took the aerial pictures by drone. 


\section{THE EXCAVATIONS ON THE SITE OF THE TEMPLE AND ITS SURROUNDINGS}

Since the central and western part of what has been identified as the temple's naos was cleaned down to the bedrock by the German team in 1987, we undertook the exploration of the easternmost part of the naos and the rectangular platform preceding it on the east (Fig. 1). The very scarce material found in the easternmost portion of the naos consisted of poorly preserved pottery sherds ranging in date from the Hellenistic to Medieval and

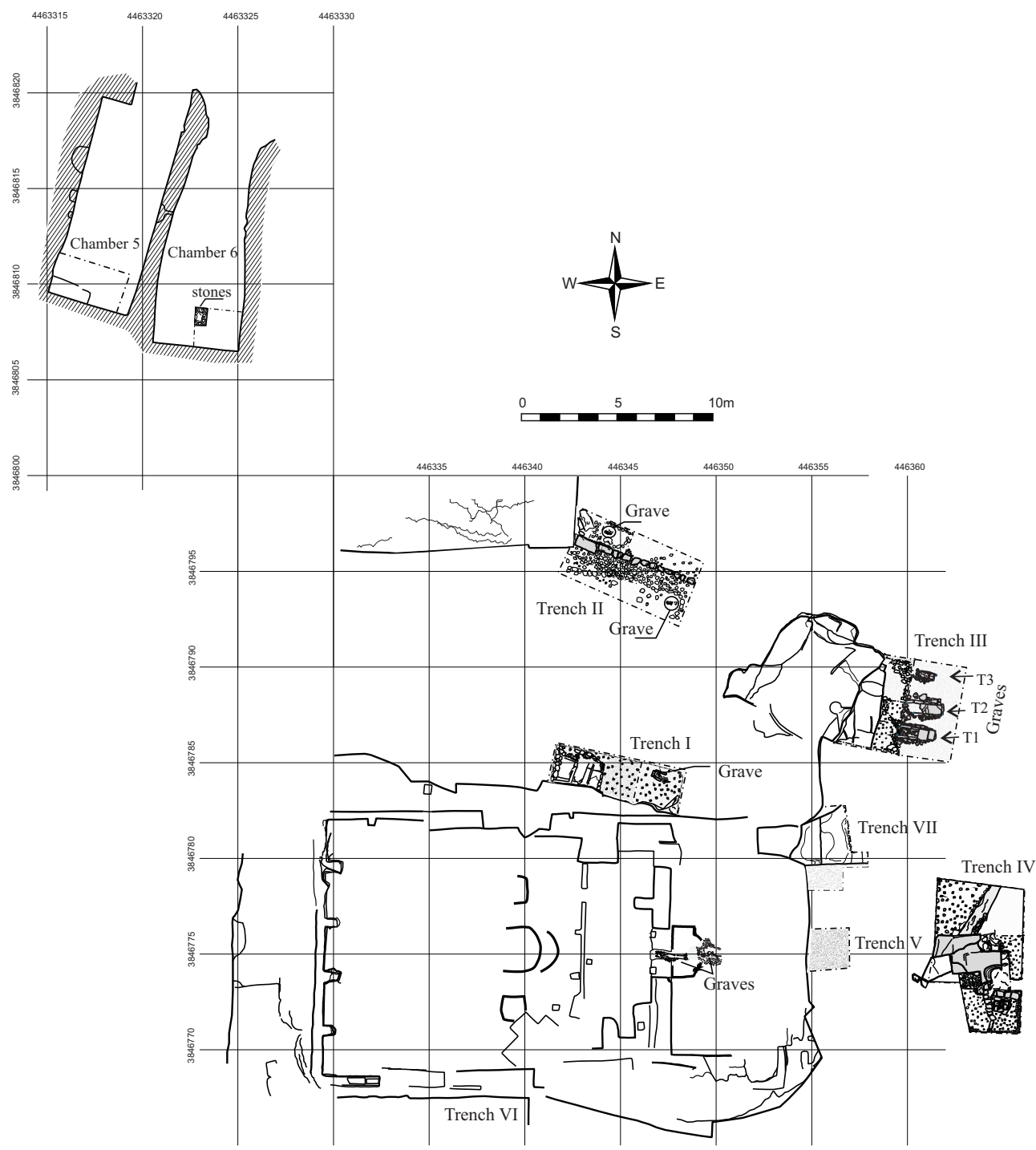

1. General plan of the temple platform and location of Trenches I-VII, as well as underground Chambers 5-6 (Drawing: M. Burdajewicz). 
Ottoman periods, occasionally mixed with modern objects; obviously, there was no chance to get any hint as to the time of the temple's activity.

The eastern part of the temple platform, identified as a pronaos in previous publications, ${ }^{9}$ is elevated $28.30 \mathrm{~m}$ asl. At the beginning of our project, it was still covered by soil so there was hope that it had not been touched by the works of the University of Trier. Indeed, after having explored this space down to the bedrock it became clear that it was the only part of the temple never excavated before. Apparently, it functioned as an un-roofed forecourt of the temple. ${ }^{10}$

After a layer c. $0.30-0.38 \mathrm{~m}$ thick consisting of small to medium-size rubble stones was removed, its central and western part revealed the presence of two skeletons, of male individuals, both buried on an east-west axis, in dorsal position, with their feet towards the east (Fig. 2). Chronologically, the first burial must have been the western one, for whom a shallow rectangular pit was dug in the entrance to the temple building. A semi-circular space was carved to the east of it, resembling an apse (Fig. 3). The second burial was deposited to the east of the first one, at a slightly higher level, the head still inside the 'apse', the rest of the body outside it to the east. This strongly suggests that the eastern deceased was buried at some time after the western one. The skull of the latter was not preserved. Perhaps it was destroyed and displaced during a later (modern?) period. No evidence of any floor was found above the skeletons. Although in the eastern part of the forecourt (outside the 'apse'), in the layer covering the burials a few fragments of the sandstone tiles were discovered, these were apparently a part of the fill.

Despite complete lack of any funerary equipment, the burials have at least an ante quem date: the layer sealing the deceased (context FAB 18-07) provided homogeneous ceramic material pertaining to the sixth century $\mathrm{AD}$, perhaps into the seventh century. The ceramic types included the Cypriot Red Slip ware forms H2, H7 and H11, African Red Slip ware forms 87 B-C and 93B, Late Roman C ware form 3 and amphorae Peacock Williams Classes 44 and $49 .{ }^{11}$ Other finds from this layer include: fragments of the abovementioned sandstone tiles (flooring?), several rather small pieces of terracotta roof tiles and bits of marble wall facing(?) as well as single large mosaic cubes and some parts of glass vessels. One of the possibilities is that all those may have come from the destruction of a very small church. The chancel part of this (an apse flanked by pastophoria), cut into the bedrock, is still visible in the central part of the naos of the temple. ${ }^{12}$ Who were the persons buried to the east of the church? They must have been persons of merit, almost certainly connected with the foundation or/and activity of the tiny church.

One should note that the above-discussed Byzantine-period burials were deposited upon the bare rock, and there were no traces of a possible original floor of the temple; if there was any, it would probably have been removed during the Byzantine era occupation. Carving

\footnotetext{
${ }^{9}$ Młynarczyk 1985; 1990; Balandier 2015.

${ }^{10}$ For the exploration of this part of the temple carried out in 2018, see: Młynarczyk 2020: 62-63 and Pl. 2:1.

11 According to the typology by Hayes 1972 and Peacock, Williams 1986; see: Młynarczyk 2020: Pl. 2:2.

12 Balandier 2015: 164, n. 8.
} 


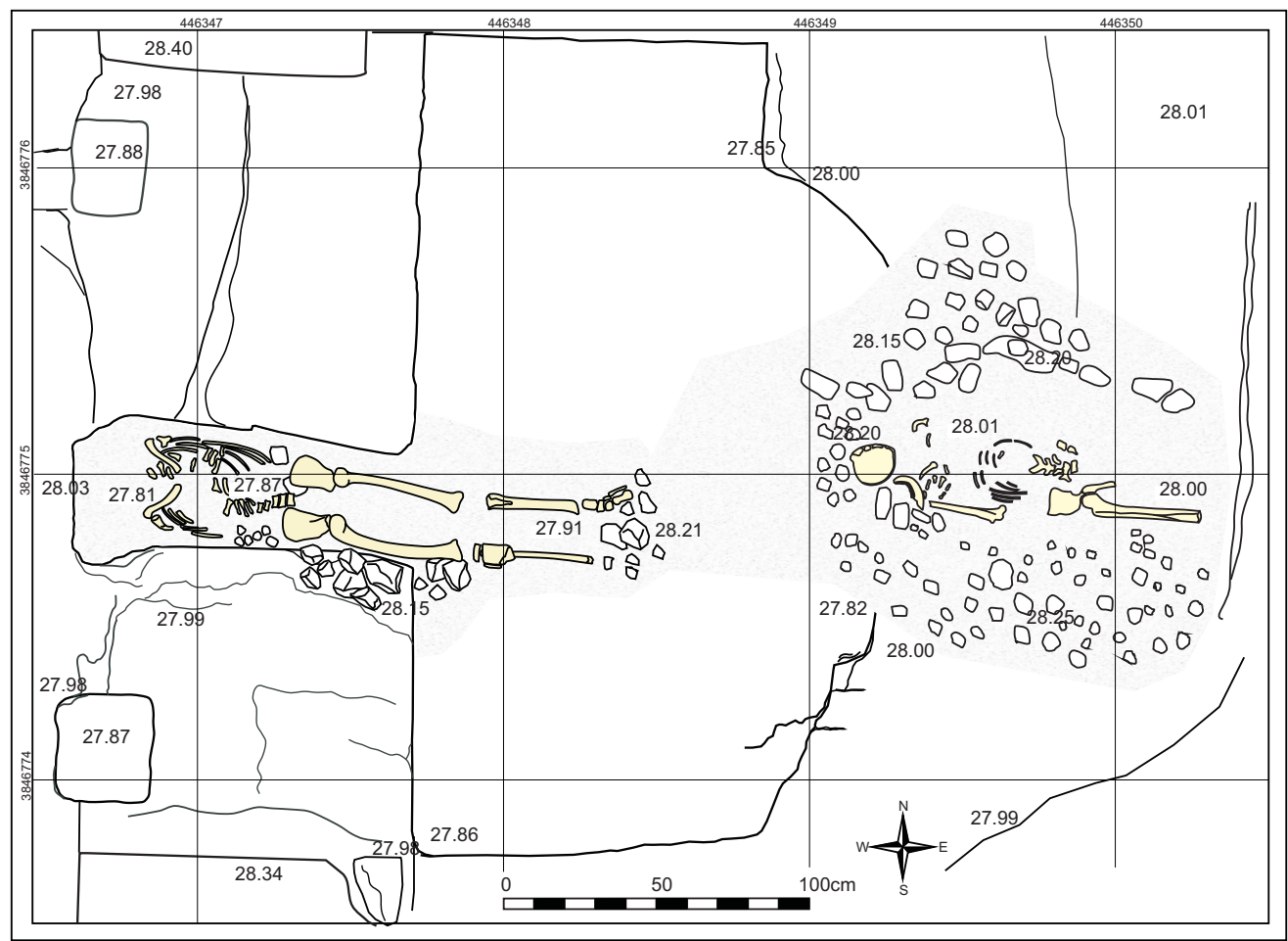

2. The two burials in the forecourt of the temple (Drawing: M. Burdajewicz).

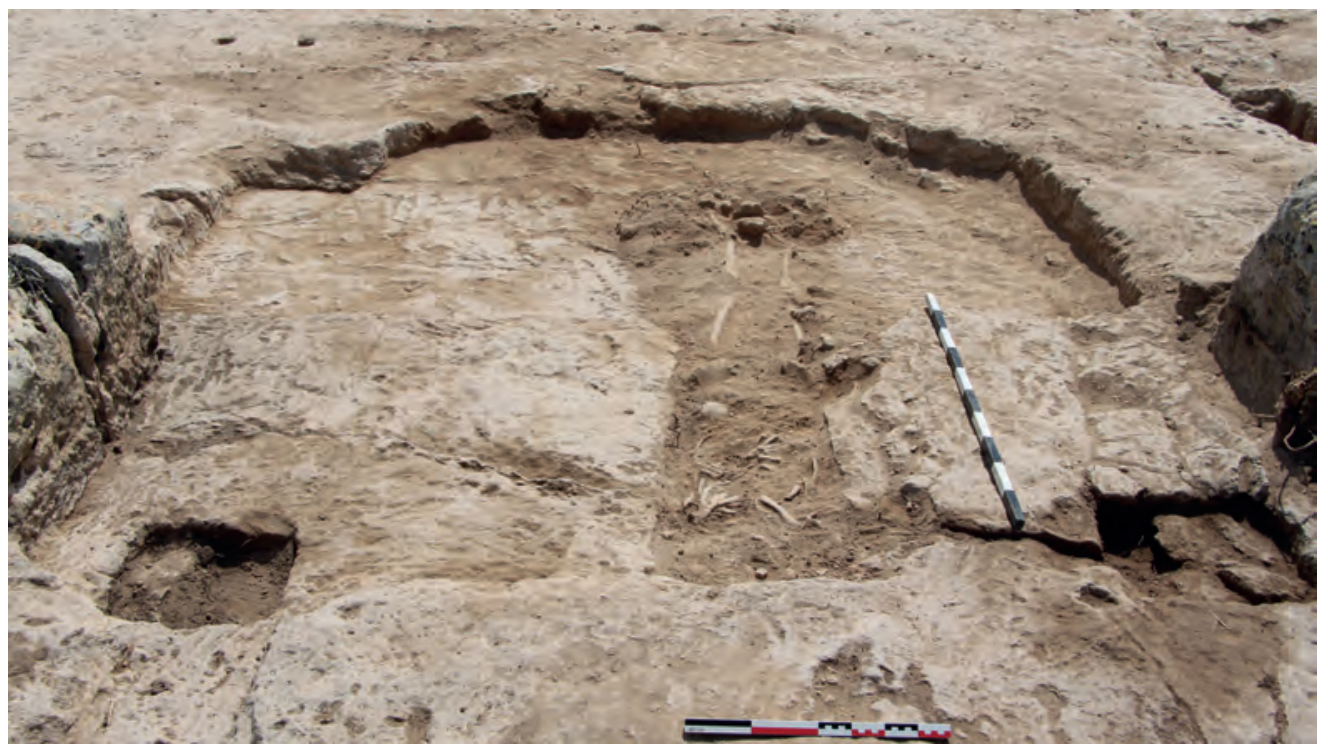

3. A burial in the apse cut into the bedrock of the forecourt; view to the east (Phot. C. Balandier). 
a grave and an apse-like space for the first burial must have necessitated removal of the floor, if there was any. Two bronze coins were found in this area (context FAB 18-07): one in the north half of the forecourt, another in its southern part, in a crevice of the bedrock. ${ }^{13}$ The first one is a late Roman coin minted during the reign of Theodosius I (type SALVSREIPVBLICAE) and the second one was minted at the end of the reign of Cleopatra VII.

Hoping to get more information regarding the temple, three trenches (I-III) were opened in 2018 to the north and north-east from the presumed monument (Fig. 1).

Trench I was situated along the northern side of the temple platform with the aim to find any floor connected with the usage of the temple building. ${ }^{14}$ However, no definite occupation level could have been noticed. Under a humus layer with mixed material (including modern one), a layer of small stones (context FAB 18-15) was found at a height of $c .27 \mathrm{~m}$ asl. It contained pieces of pottery dated to the second half of the first century AD and first half of the second century AD (in addition to some late Hellenistic potsherds), few fragments of marble, terracotta and sandstone tiles, rooftiles, and single mosaic cubes. Underlying this layer was a fill of stones in a soft soil (context FAB 18-17) with fewer pottery of the same date as above, quite a lot of parts of rooftiles, some fragments of terracotta tiles and water pipes, as well as single pieces of vividly painted wall plaster. The layer produced also a part of a limestone column drum with reconstructed diameter amounting to $0.43 \mathrm{~m}$. It was coated with plaster painted in imitation of greyish-blue marble. This thick layer was identified as deposited in a single episode about the mid-second century AD, as indicated by the latest pottery finds filling of an open-air stone quarry whose bottom layer was reached at a depth of c. 25.20m asl (Fig. 4).

In the north-eastern limits of the trench a grave was found (context FAB 18-21), dug into the layer of rubble fill to a depth of 26.60m asl (Figs 4-5). It was defined by three upright blocks making a pi-shaped casing on its western side, and contained remains of a child's skeleton. In the area of the skull and neck a steatite cross was found. Most probably this was a centre piece of a necklace composed of beads of pale blue glass paste and a carnelian one, found in the same spot (Fig. 6). A thin bronze (nose?) ring was recorded in the same place. The burial was accompanied by more than 430 shells of terrestrial molluscs Rumina cf. saharica. It has been assumed that the burial would be contemporaneous with those in front of the entrance to the pronaos of the temple, belonging to the early Byzantine period (sixth or seventh century?).

Trench II was opened c. 8m to the north of Trench I (Fig. 1) where a series of stones including one big ashlar formed an east-west wall visible on the surface. ${ }^{15}$ Thin layers related to this wall were dated, on the basis of some very fragmentarily preserved pottery, to the Medieval and Ottoman periods. On the southern side of the wall there was a layer

\footnotetext{
13 They have been studied by Anne Destrooper-Georgiadès after restoration.

14 For a summary description of Trench I, see: Młynarczyk 2020: 63-64, Pls 2:3, 3:1.

15 For the summary description, see: Młynarczyk 2020: 64.
} 
4. Trench I: a child's burial (foreground) overlying the fill of the quarry (background); view to the west (Phot. J. Młynarczyk).
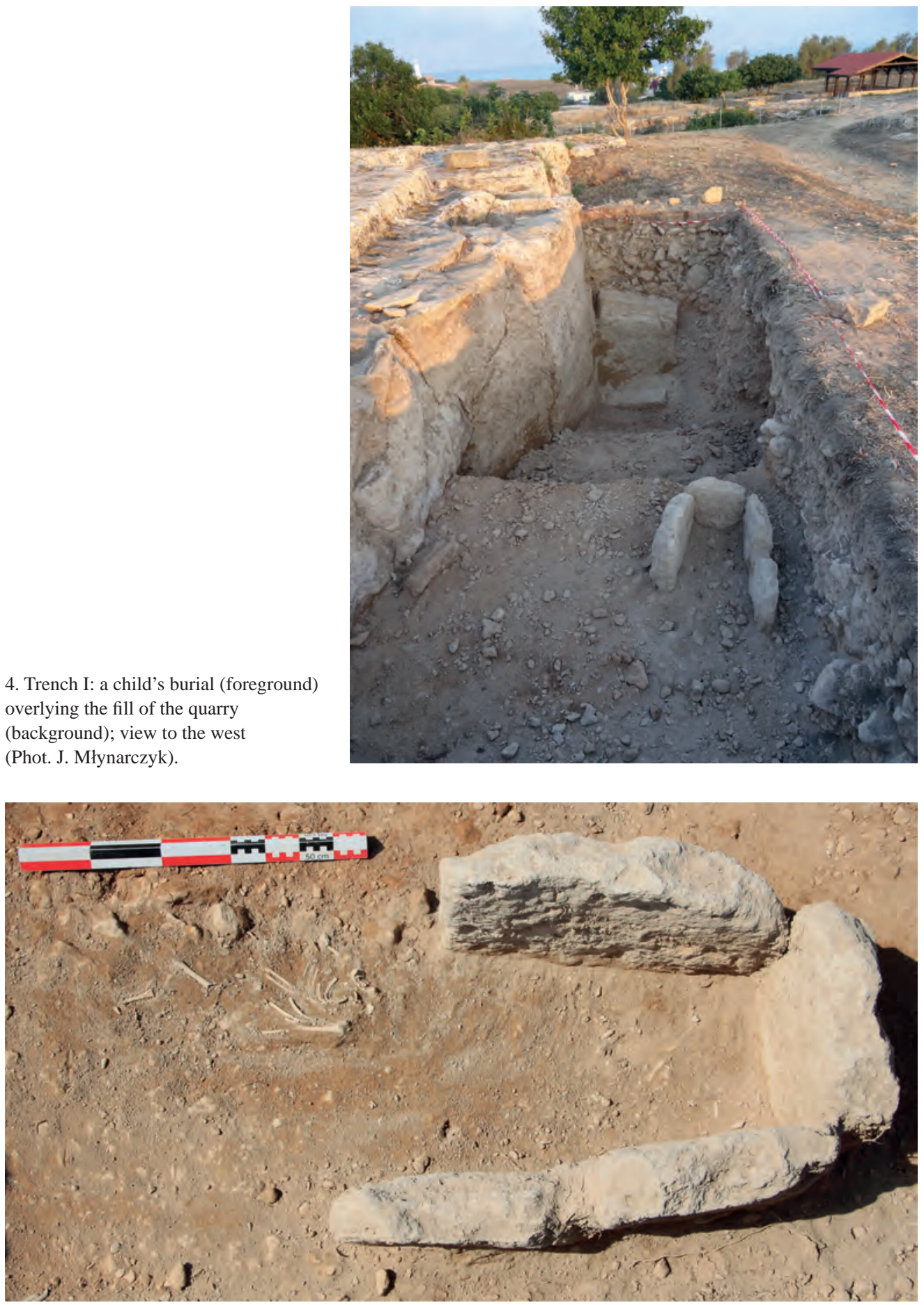

5. Trench I: a child's burial at the moment of discovery; view to the south (Phot. C. Balandier). 


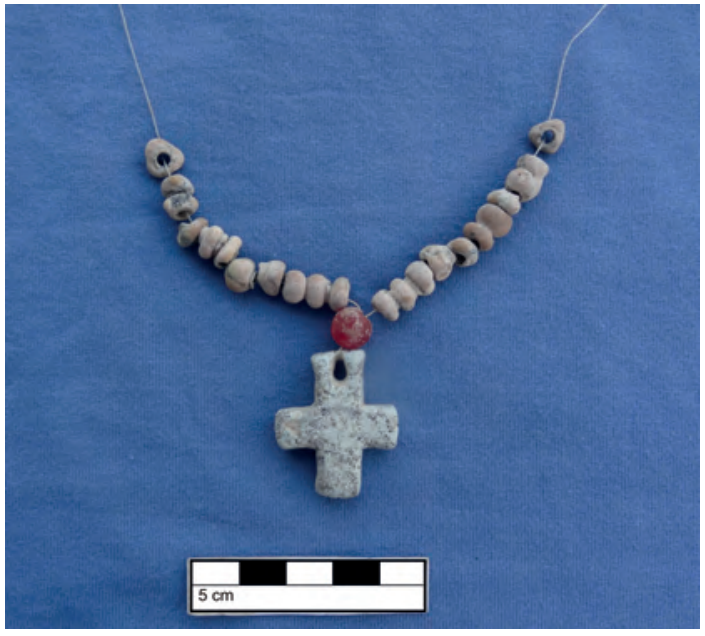

6. The restored necklace from the child's burial in Trench I (Phot. M. Burdajewicz).

of cobble stones apparently related to it (Fig. 7), perhaps the remains of a street or of a courtyard. A layer underlying those Medieval or Ottoman period remains has been tentatively dated to the Roman period on the basis of ceramic sherds. Into this layer, two infant burials were dug, one (context FAB 18-28) in the south-eastern part of the trench, and another (context FAB 18-33) in the north-western part (Fig. 8). The poorly preserved skeletons were devoid of any accompanying objects except for many terrestrial mollusc shells, but on the basis of stratigraphy one may suppose that they were contemporaneous with the child's burial in Trench I and the adult burials in front of the entrance to the pronaos of the temple, which would date them to the early Byzantine (late Roman) period (c. sixth-seventh century). However, given the lack of any firm chronological indication, a later, Medieval period date cannot be excluded.

Trench III $^{16}$ was opened to the north-east of the temple platform, on the eastern side of a rock-cut or semi-natural elevation, roughly semi-circular in shape (nearly circular on drone pictures taken by the French Mission before cleaning). On its south-western side traces of a rock-cut very narrow channel, circle-quarter in plan and descending to the south-east were recorded (Fig. 1). The eastern part of this rocky outcrop has been entirely exposed, revealing a kind of two long curved steps ('shelves') descending to the east and slightly sloping southward. The flat surface of the upper one features an omega-shaped cavity (c. $0.69 \mathrm{~m}$ in diameter and $0.20 \mathrm{~m}$ in depth) with two diverging grooved channels on its eastern side (Fig. 9). ${ }^{17}$ Along the edge of the lower step, a small test trench made

16 Młynarczyk 2020: 64-65, Pl. 3:2.

17 At first glance it looked similar to an oil pressing arrangement carved in the bedrock and known elsewhere in Cyprus and Near East, or to evidence of quarrying activity (stone extraction for a column), but during the recent field season (June 2021) the rock feature in question has been identified as an open-air stibadium. 
7. Trench II: the east-west oriented wall with a layer of cobble stones against its southern face; view to the east (Phot. C. Balandier).

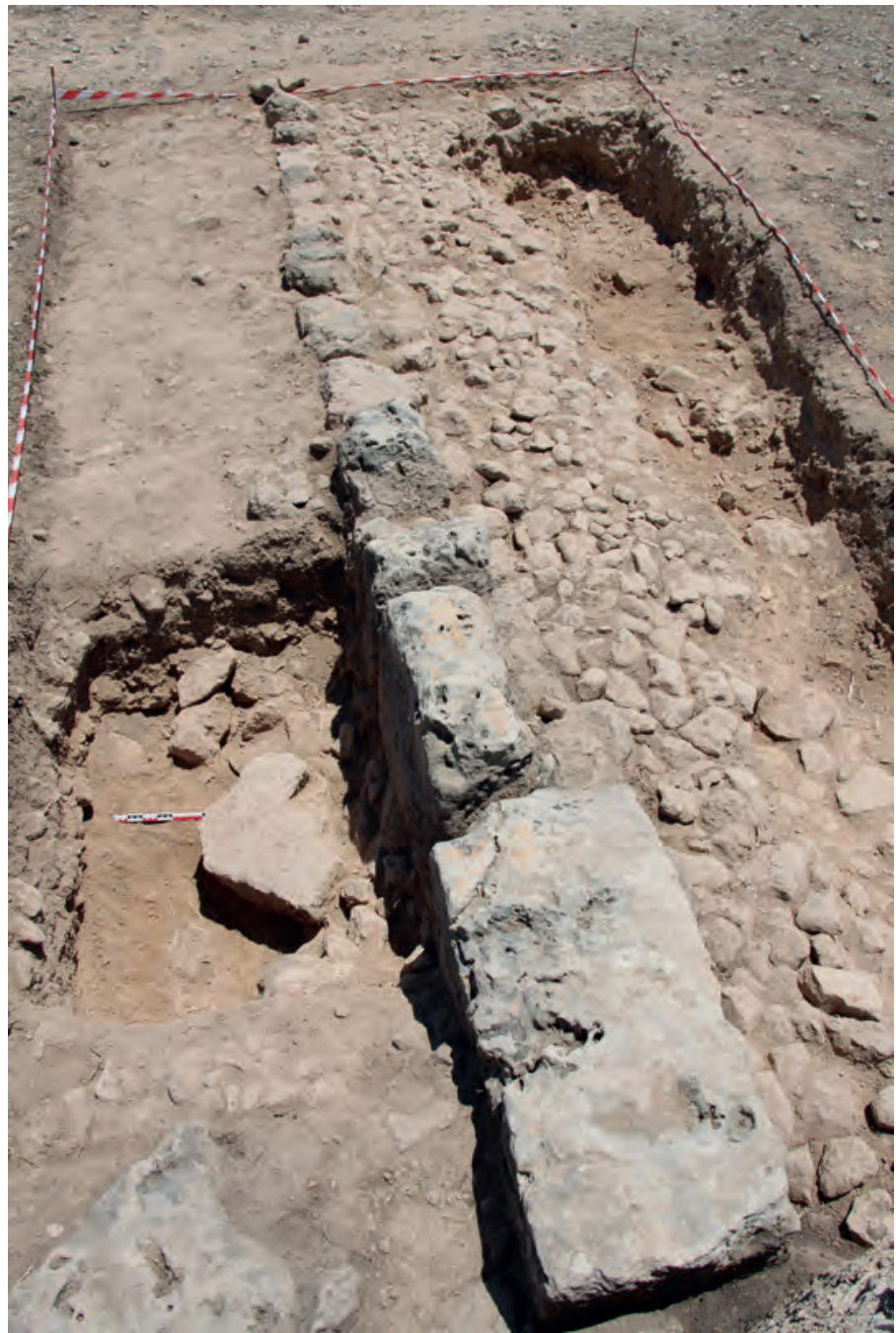

in 2018 yielded archaeological material (context FAB 18-34) in terms of chronology very similar to that found in Trench I. The northern part of the test trench revealed a loose fill of stones (including fragments of stone vessels), while the southern one yielded several architectural fragments, wall plasters and many pieces of gypsum mortar. In both parts the pottery was very homogeneous in terms of the dating, covering the late first to mid-second century AD (with some late Hellenistic admixture). This layer seems to date the abandonment of the temple area.

During the field season of 2019, it was decided to extend Trench III by $3 \mathrm{~m}$ to the east in the hope of finding an occupation level, possibly matching the early Roman chronology of the pottery finds. About $0.20-0.30 \mathrm{~m}$ below the surface, three graves (marked as T1, T2 


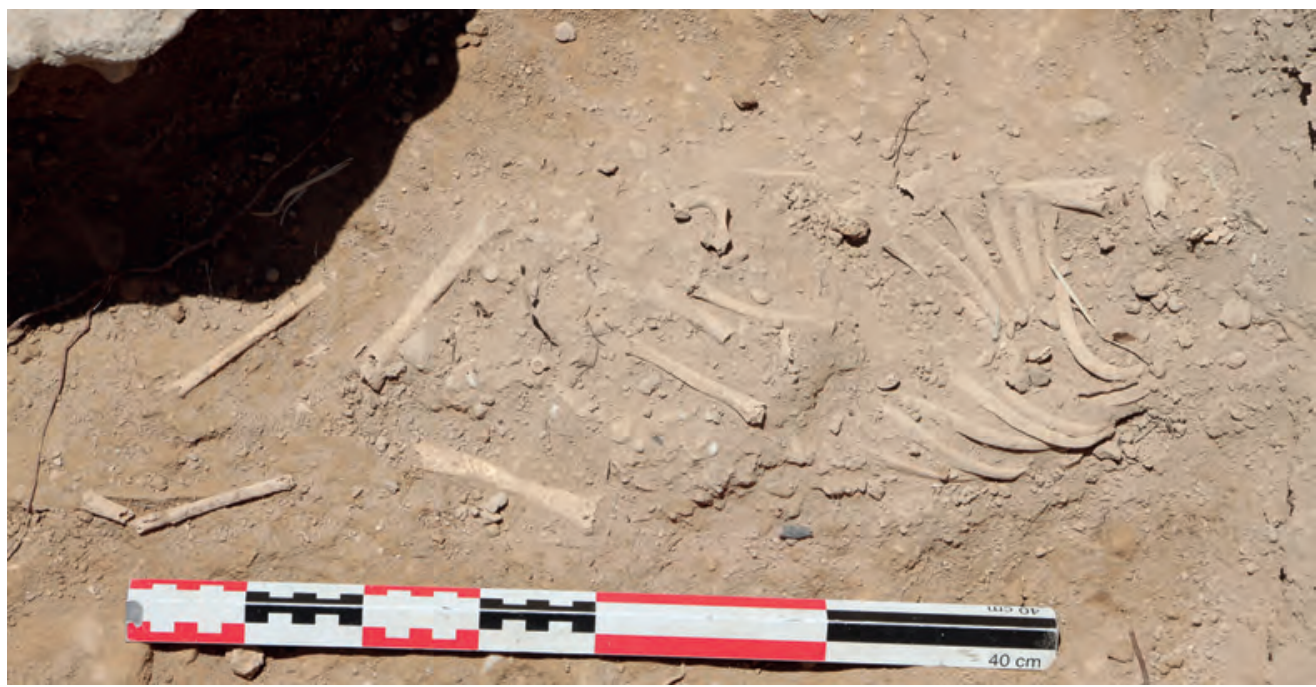

8. Detail of the child's burial in the north-west corner of Trench II; the north at the bottom (Phot. C. Balandier).

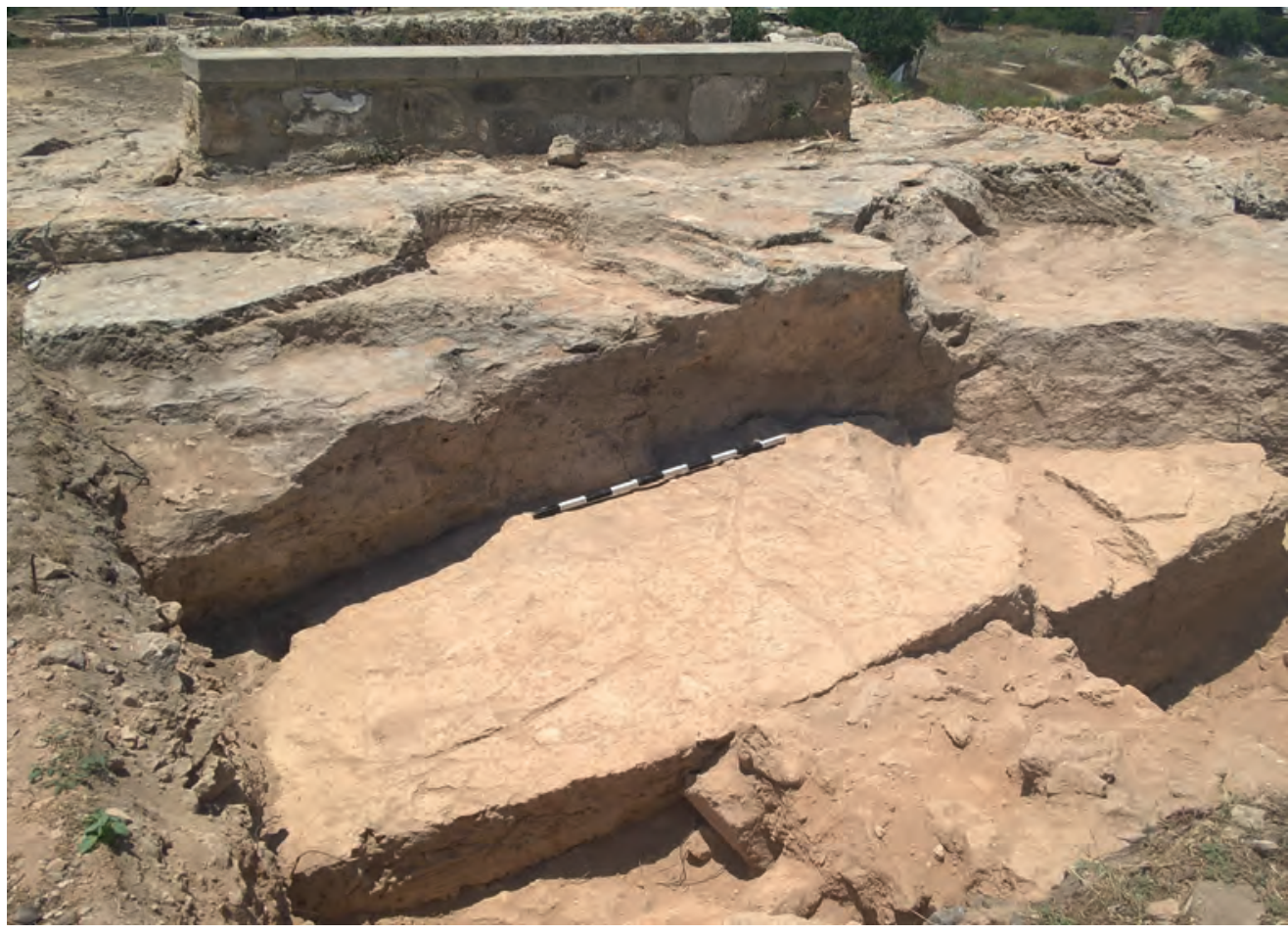

9. General view of the Trench III in 2018 season; view to the west (Phot. M. Burdajewicz). 


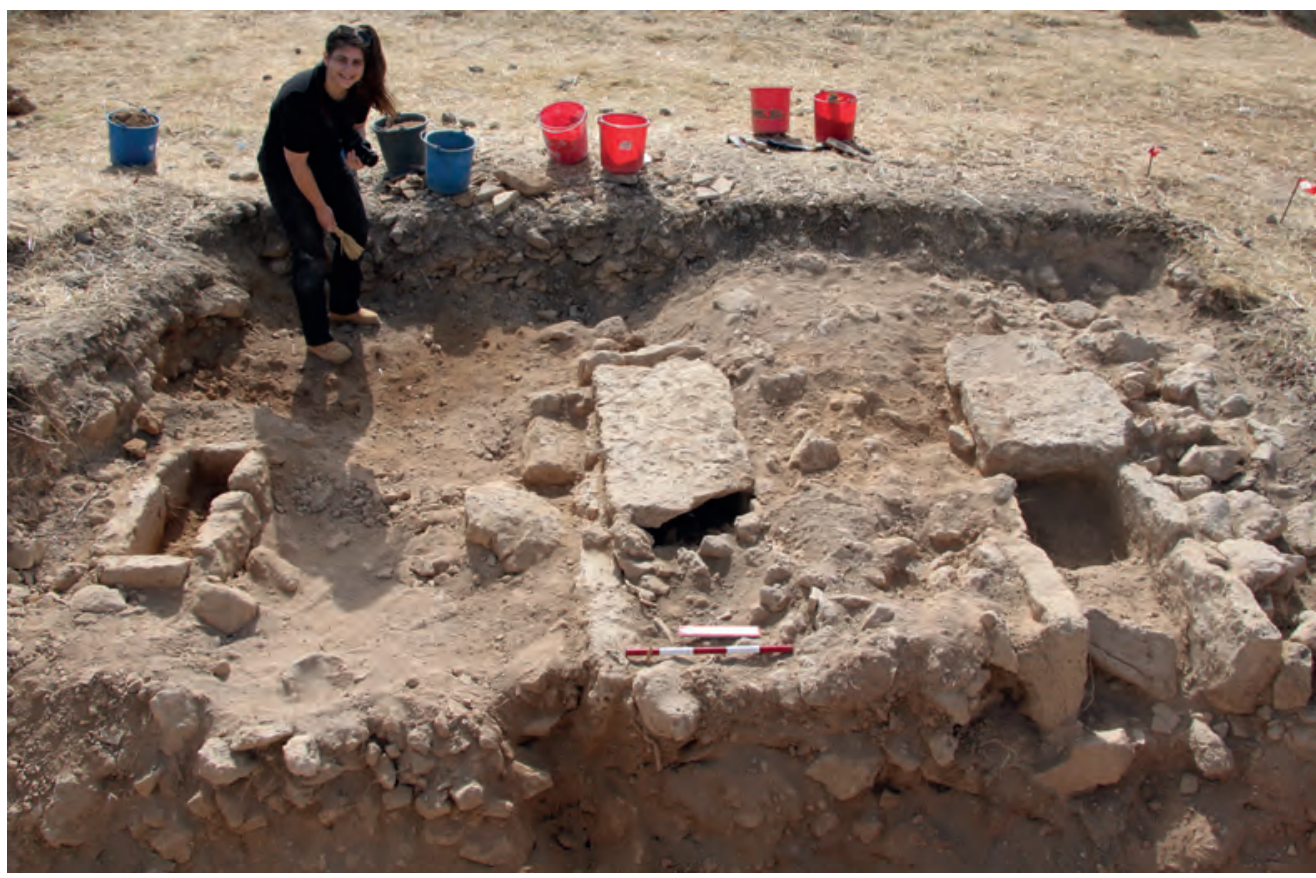

10. Trench III: the three tombs dug into an earlier stone fill; view to the east (Phot. C. Balandier).

and T3 from south to north) were noted, all aligned on an east-west axis (Fig. 10). They were rather carelessly constructed of, and covered by, limestone slabs. Of those, only the southernmost tomb (T1) contained a skeleton of an adult, probably male, his head (not preserved) to the west, the legs to the east. The middle tomb (T2) was found empty. Both T1 and T2 were slightly trapezoid rather than rectangular in outline, narrowing toward their eastern ends, and both of them lacked cover slabs at their western ends, which might suggest that they had been disturbed by looters searching for personal jewellery of the deceased such as earrings, necklaces etc. However, even the northernmost, and at the same time the smallest tomb (T3), covered completely by three slabs and without traces of later disturbances, was also found empty. It could have belonged to an infant whose bones were not preserved. Like the burials of children excavated in Trenches I and II during the 2018 season, also this tomb contained many shells of small terrestrial molluscs Rumina cf. saharica. Curiously, the same type of shells occurred in the empty T2, while they were totally absent in T1.

The layer in which the graves were dug into was not quite homogeneous. While grave T1 was surrounded by compacted stones, especially on its southern side, the fill under and around T2 and T3 was rather crumbly. The graves did not contain any funerary equipment that would help to determine the date of the burials. However, some ceramic fragments representing late Roman types, such as the CRS and ARS wares, coming from the contexts related with foundation of the graves (specifically, contexts FAB 19-02, 03, 06, 09) allow 


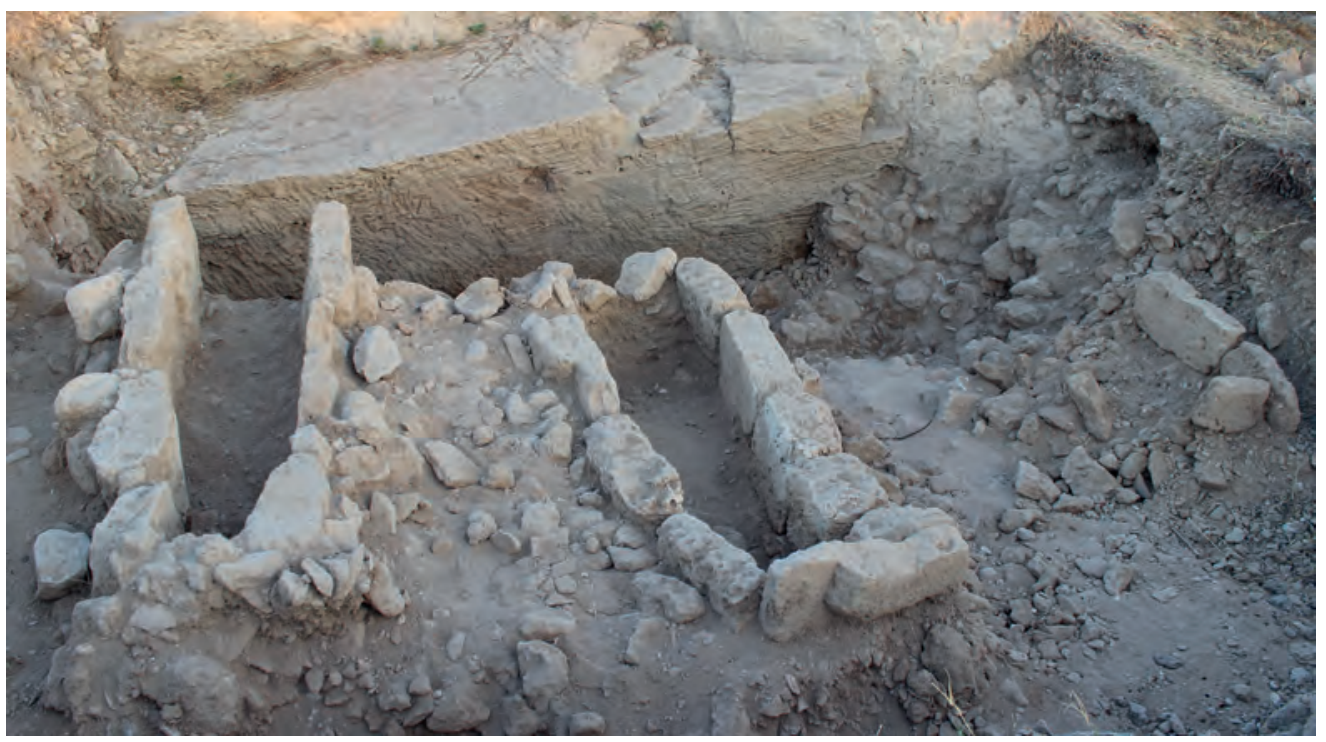

11. Trench III: tombs T1 and T2 dug in the earlier stone fill; a small niche carved in the eastern face of the rocky outcrop; view to the west (Phot. J. Młynarczyk).

one to attribute them to the sixth, perhaps into the seventh century. On the other hand, a Medieval date cannot be excluded, given the graves' resemblance to at least three graves that were discovered earlier at the eastern edge of Fabrika (Chantier B), to the north of the Roman cistern, and tentatively attributed by the French researchers to the Frankish period. ${ }^{18}$

Unfortunately, the discovery of the graves and the necessity to preserve their construction precluded further exploration in this spot, leaving no chance to understand the earlier history of the area. The layers below the level of the graves could have been investigated only within a narrow space (just $1.20 \mathrm{~m}$ wide) compressed between graves and quasi-vertical face of the rock-cut feature on the west (Fig. 11). The part of the fill (contexts FAB 19-41, 42,43 ) underlying graves level consisted of medium- to large-sized stones, mostly irregular, with occasional dressed blocks. It contained large pieces of transport amphorae and less frequent examples of cooking and fine wares. All the ceramics were exclusively of the late Hellenistic and early Roman date, i.e. of the second century $\mathrm{BC}$ to the first half of the second century AD (Fig. 12). Other objects from the fill are: occasional fragments of water pipes and rooftiles, small parts of architectural elements as well as fragments of stone vessels. For the sake of work safety, the exploration had to be halted at the height of $24.80 \mathrm{~m}$ asl,

18 Balandier, Morvillez 2009: 443, n. 3; Balandier 2012: 160 and Fig. 10. However, since the burials contained no funerary equipment and the stratigraphy of the area still remained to be specified, it cannot be excluded that they could be of the late Roman/early Byzantine period. The slabs covering the tombs were found at the same level as a floor connected to a medieval wall (end of the thirteenth or fourteenth century AD?) but the bottom of the tombs was dug in a thick fill dating to the late Roman period (few sherds of amphorae of the fifth century $\mathrm{AD}$ were identified according to a preliminary expertise made by Antigone Marangou-Lerat on the site). 

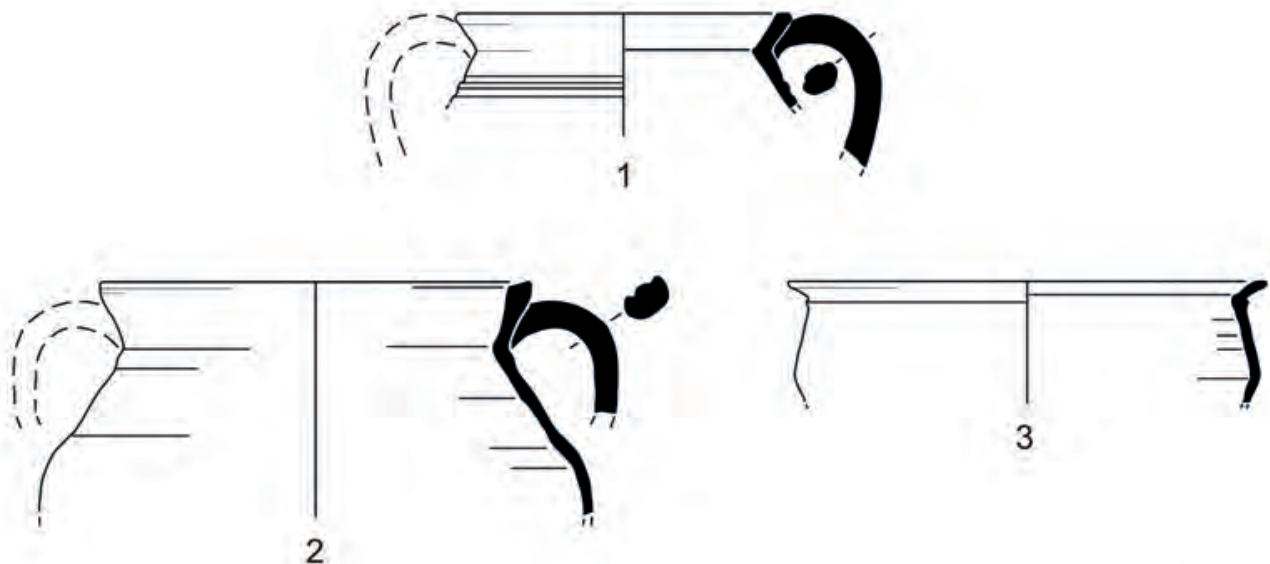

3
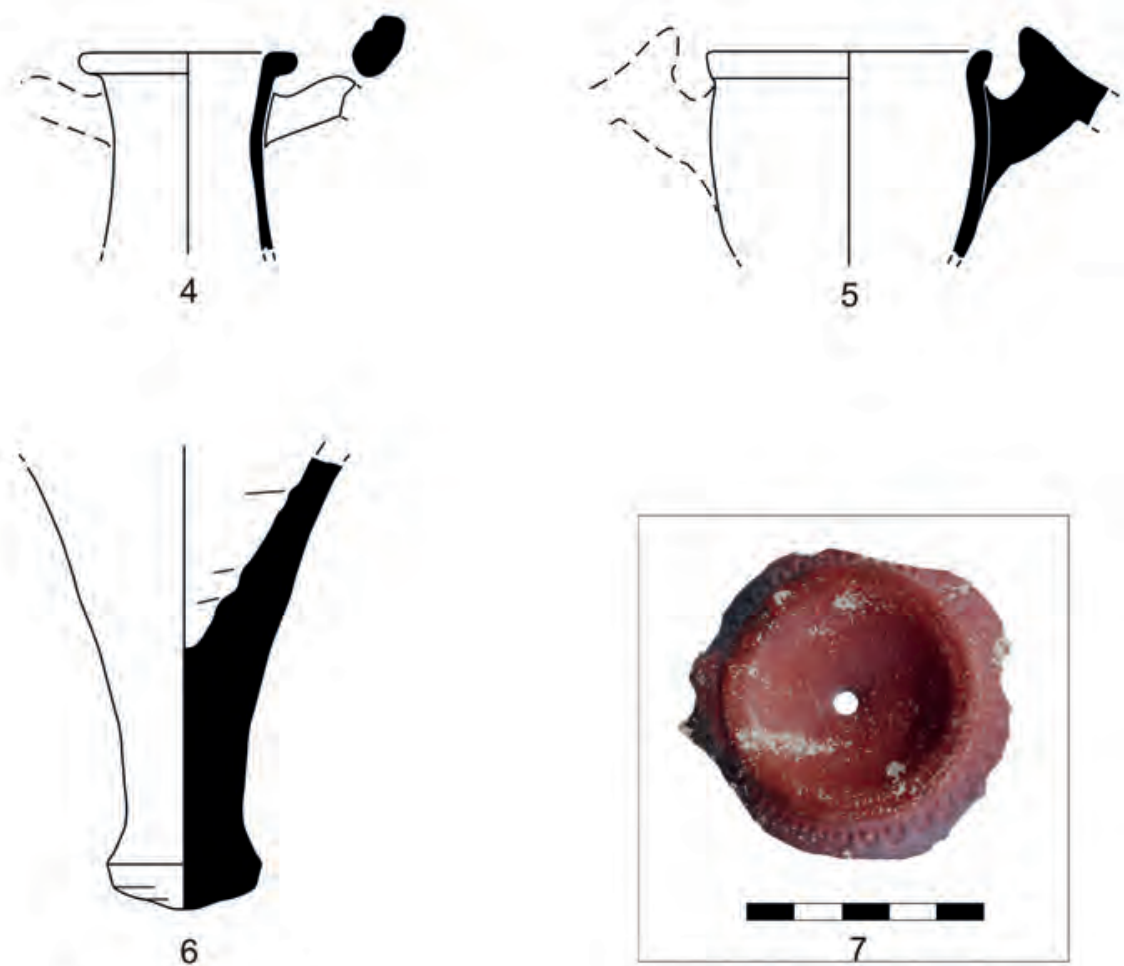

0

$10 \mathrm{~cm}$

12. Trench III: sample of ceramics from the stone fill (context FAB 19-41), including a lamp fragment of the early second century AD (Phot. J. Młynarczyk; drawing: M. Burdajewicz). 
that is, approximately $2.12 \mathrm{~m}$ below the top of the fill and $1.50-1.77 \mathrm{~m}$ below the bottom level of the graves.

It is difficult to propose any sound interpretation for the original purpose of this deep artificial cut in the rock, whose extent and depth both remain undefined. Was it a water cistern similar to the one discovered by the French team further to the east? ${ }^{19}$ However, no traces of waterproof coating were found. Was it a quarry? Yet, the fill looks very different from the quarry fill noted in Trench I. A puzzling feature is a small niche carved in the eastern face of the rocky outcrop, of the type used to accommodate a lamp (Fig. 11). Its presence in a place that was not roofed is difficult to explain, unless it was a kind of a small votive niche.

During the 2019 field season, four more trenches (IV-VII) were opened at different spots outside the temple platform. The below presentation is given in an order facilitating understanding of the achieved results, and does not follow the numerical order of the trenches.

Trench VI covered the eastern half of a roughly semi-circular rocky terrace doubtlessly of artificial origin and situated to the south of the naos (Fig. 1). ${ }^{20}$ Under the humus layer with occasional Ottoman and modern material, there were two layers of soil, mostly loose ('sandy') in appearance, to the total thickness of $0.60-0.70 \mathrm{~m}$, of which the lower one contained modest amount of small and medium-sized stones. Underneath, a quasihorizontal surface of the bedrock has been exposed at $c .1 .00-1.20 \mathrm{~m}$ below the edge of the naos level. The few finds retrieved from this trench include small potsherds ranging in date from the early Roman to the Medieval period. It is possible that the layers in question could be recognised as related to the cleaning of the naos area conducted by Grimm in 1987. Thus far, there are no clues as to the function of this terrace during any historical period.

Trench V, in shape of a small square $(2.20 \mathrm{~m}$ by $2.20 \mathrm{~m})$, was opened strictly on the axis of the naos, against the eastern vertical rock-cut face of the temple platform (Fig. 1). ${ }^{21}$ It was intended to check for the presence of possible traces of an axial access to the temple. The results have been definitely negative: the trench turned out to be completely sterile in terms of architectural remains. While the humus layer (FAB 19-21) contained several Byzantine and medieval potsherds, the pottery found in subsequent layers (FAB 19-22 and 19-23) was related exclusively to the Hellenistic (mainly second-first centuries BC) and early Roman (till the first/second century AD) periods, with no later evidence. They were accompanied by small pieces of painted plaster and fragments of two limestone bowls. The stone fill of Trench V closely resembled that of the lower part of Trench I identified as a quarry fill. Therefore, upon having reached the layer of small stones and stone chips, the exploration of Trench V was halted at $25.15 \mathrm{~m}$ asl.

\footnotetext{
19 Balandier 2012: 158, Fig. 8.

20 Cf. Młynarczyk 2020: 65-66.

${ }^{21}$ Summary presented in: Młynarczyk 2020: 66.
} 


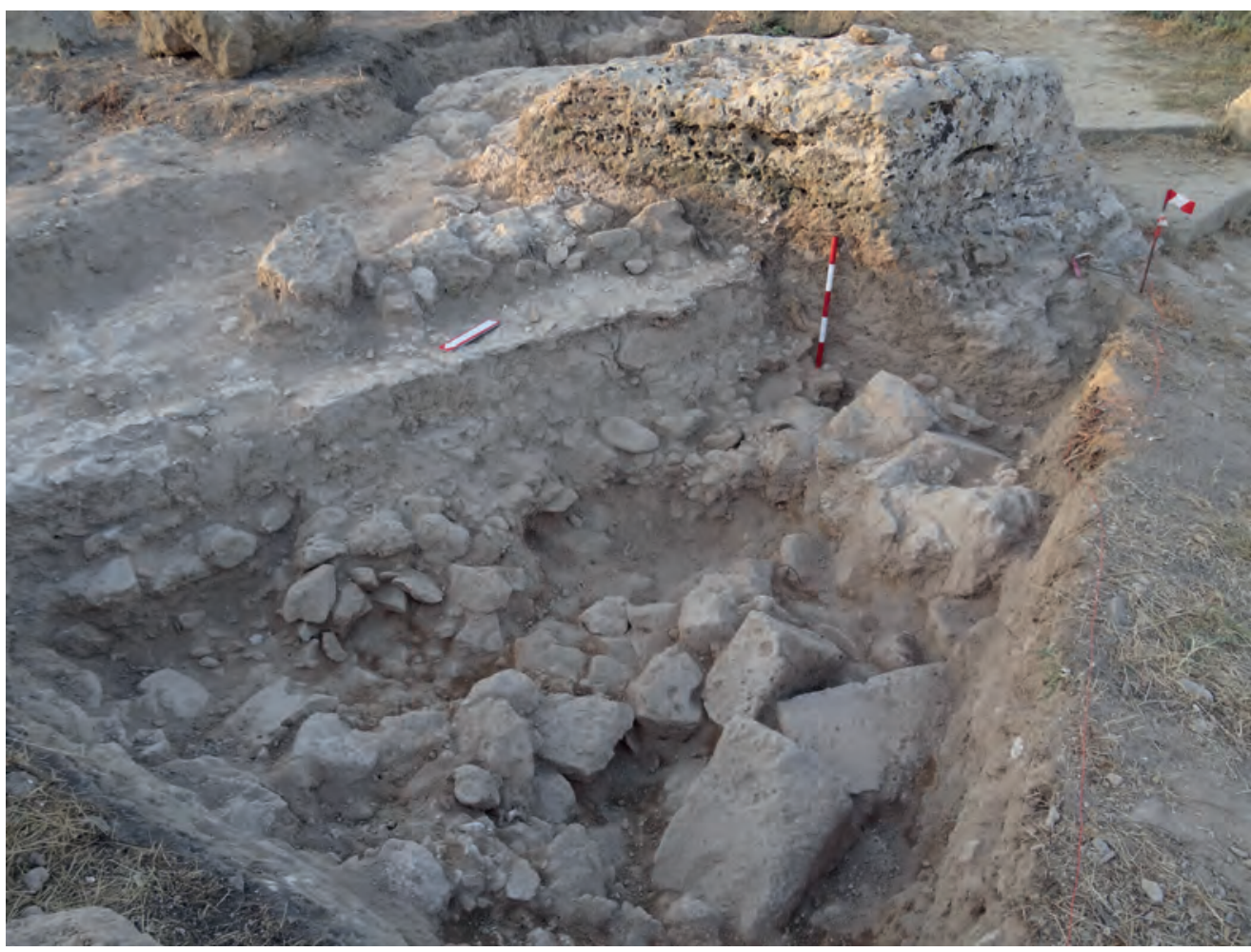

13. Trench IV-North: thick layer of debris of stones and dressed blocks; view to the south (Phot. M. Rekowska).

Trench IV was opened some $7 \mathrm{~m}$ to the east of the temple platform, on its long axis (Fig. 1). ${ }^{22}$ It was aimed to check if the carved rocky outcrop situated on the axis of the temple and in front of its façade could be interpreted as an altar. Unfortunately, the trench could not be extended to the west, that is, towards the temple platform, due to the presence of a tourist path leading up to the viewpoint above the theatre. The excavation was carried out on two sides, northern and southern ones, of the protruding rocky outcrop. Its northern, western and southern sides were worked into smooth vertical surfaces, but a large part of this elevation was destroyed by erosion.

In the northern part of the trench (Trench IV-North), at c. $0.10 \mathrm{~m}$ below the present ground level, an earthen surface was found, apparently the most recent (Ottoman?) 'walking' level. At its western end, poor remains of a NE-SW oriented, diagonally to rocky outcrop, wall were found, supported with a very strong cemented substructure. To the west of it, there was a dense and thick debris of collapsed stones, including large dressed blocks (Fig. 13). It seems that the debris antedates the construction of the above-mentioned 'diagonal' wall, since the probable occupation level corresponding to the wall is visible as a whitish line in

${ }^{22}$ Preliminary information on this trench were given in: Młynarczyk 2020: 66-67, Pl. 4. 


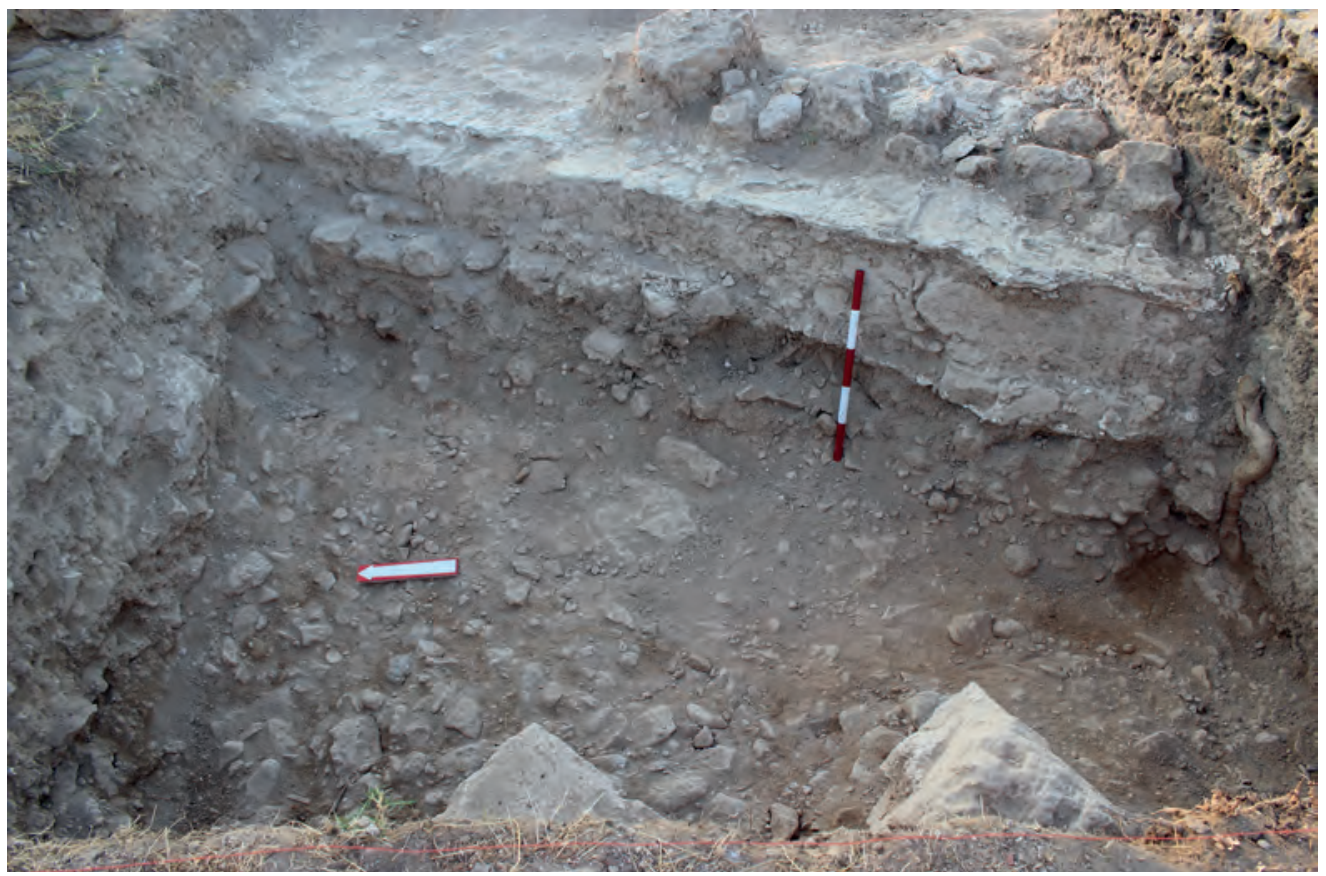

14. Trench IV-North: floor made of small stones mixed with earth; view to the east (Phot. M. Rekowska).

the northern section of the trench above this layer. The debris in question were lying over another floor made of small stones mixed with earth at $26.35 \mathrm{~m}$ asl (Fig. 14). The material from the layer between the debris and the floor (context FAB 19-52), as well as from below this floor (context FAB 19-53) contained medieval glazed pottery. This means that there were two consecutive phases of the Medieval-period architecture, perhaps topped by an Ottoman phase. The exploration of this part of the trench was halted at $25.95 \mathrm{~m}$ asl.

In the southern part of the trench (Trench IV-South), the cleaning of the south-eastern part of the rocky outcrop revealed the presence of a rock-cut basin of which just one quarter has remained. The basin, cubic outside and conical inside, was c. $0.70 \mathrm{~m}$ deep, and it was clearly carved as a part of what we have tentatively identified as a rock-cut altar (Fig. 15). Abutting the rocky outcrop from the south there was a floor, partly in the form of a pavement made of small stones (27.85m asl), and partly of tamped earth. In the south-eastern part of the trench, a curved wall was discovered with a stone debris on its southern side. These may represent one or even two phases of medieval occupation. After removal of the aforementioned debris in the south-eastern corner of the trench, a very shallow foundation for the curved wall was noted. Below, at $26.60 \mathrm{~m}$ asl, there were flat irregular stones that resembled a paving (Fig. 15). Interestingly, the ceramic material retrieved from under the debris, that was found upon the paving, pertained to the late Roman/early Byzantine period, but no material could be clearly associated to Medieval period. The above described remains are perhaps chronologically and even functionally related to a building 


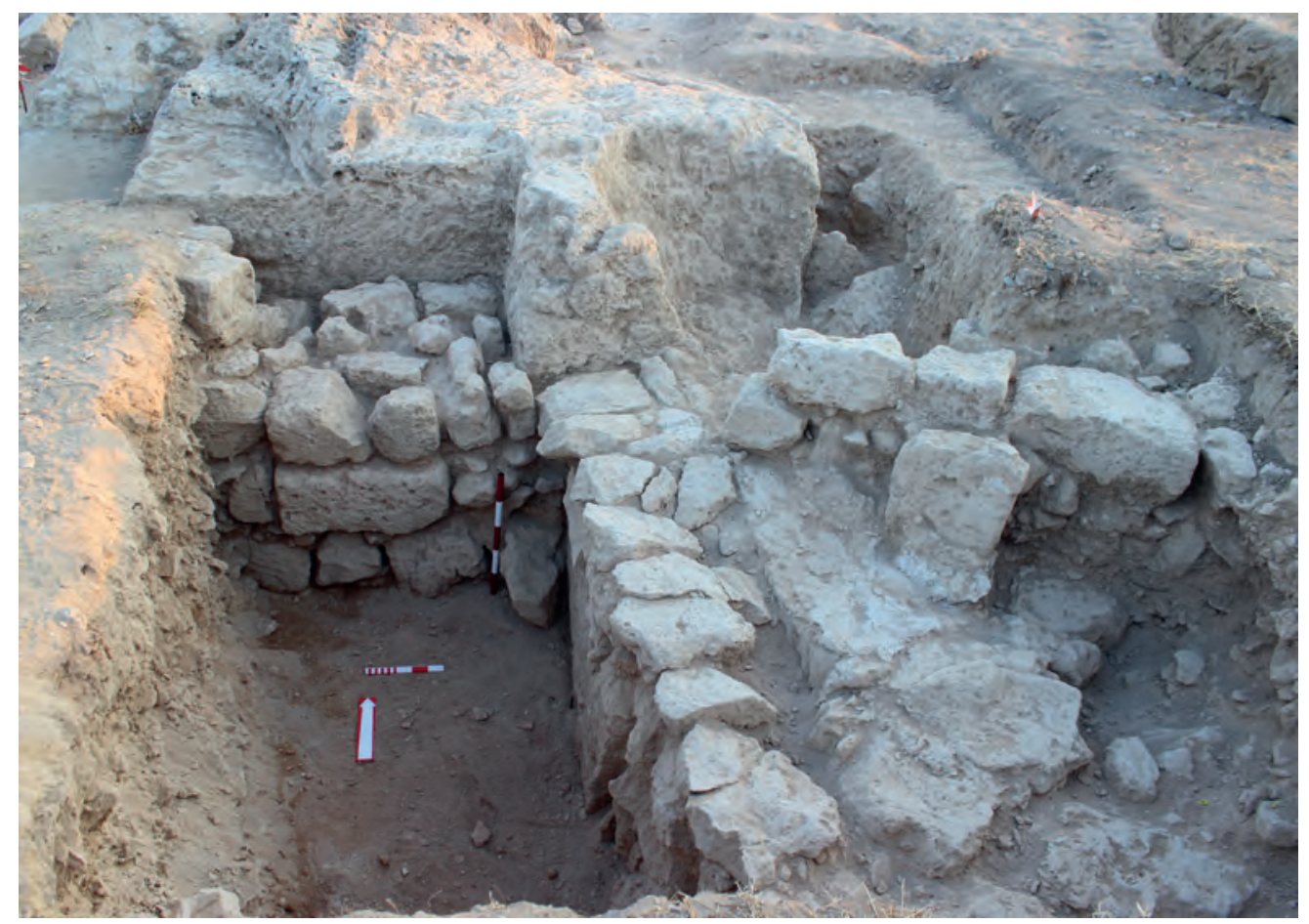

15. Trench IV-South: walls abutting on a rock-cut basin associated with an altar; view to the north (Phot. M. Rekowska).

discovered by the Sydney University team above the theatre, that is, in the vicinity of our Trench IV. That building has been interpreted as 'medieval or post-medieval industrial structure'. ${ }^{23}$ The analysed remains could be also closely associated to the wall unearthed by the French mission few meters to the east of the altar, retaining a thick fill dating from the end of the thirteenth-fourteenth century AD overlying the Roman cistern reused in the thirteenth century, but destroyed by an earthquake soon after that. ${ }^{24}$

The paving below the curved wall abutted on a north-south oriented wall, which could be in fact a foundation wall. It was built against the remnants of the rock-carved basin and perpendicularly to the pavement of small stones, the latter put on top of an earlier wall. In spite of the insignificant dimensions of this part of the trench, there is little doubt that we are dealing with remains of a rock-cut cultic installation, apparently an altar, combined with a libation or cleansing basin. The rock-cut altars are well-known in the Cypriot religious tradition as testified by the late Cypro-classical representations on votive reliefs from the sanctuary at Ayios Photios in Golgoi. ${ }^{25}$ However, the restricted space of the trench

23 Barker 2015: 186, Pls 11-12.

24 Balandier, Morvillez 2009: 439-441; Balandier 2012: 160-161.

25 Hermary, Mertens 2015: nos 448, 450-451. 
and the concentration of architectural remains from several periods (doubtlessly Medieval, but also late Roman/Byzantine and perhaps Hellenistic-Roman) do not allow for the precise dating of the particular architectonic phases. The exploration of the space within the south-western corner of the trench was stopped at the height of $26.30 \mathrm{~m}$ asl, in a layer of soft brown soil with bits of lime mortar. At that level, the north-south wall foundation seems to be built on the bedrock, while the east-west wall apparently continues deeper. No definite floor has been reached yet, but the scarce pottery finds, accompanied by small fragments of painted plaster, seem to date from the late Hellenistic to early Roman periods.

Trench VII was opened just off the north-eastern corner of the temple platform, in a narrow space limited on the east and north-east by the tourists' path (Fig. 1) ${ }^{26}$ The trench revealed a rock-cut entryway into the outer lower part of the forecourt of the temple. It consisted of a step $2.40 \mathrm{~m}$ wide and $0.98-1.20 \mathrm{~m}$ deep (probably a substructure for stairs) with a curved parapet on the southern side, and an almost horizontal ramp below (Figs 16-17). Such non-axial location of the entrance to a sanctuary is rooted in the indigenous tradition of Cypriot sacred architecture going back to the Late Bronze Age.

The whole extent of the ramp, which was unearthed to a length of $2.45 \mathrm{~m}$, could not be exposed due to the presence of the aforementioned path. Cleaning of the ramp revealed a north-south oriented wall made of rubble, apparently of a relatively recent date, crossing the ramp itself. To the contrary, a small space excavated to the south of the entryway (contexts FAB 19-62 and 19-65) yielded abundant material dated to the Hellenistic and early Roman periods. Beside the pottery, these seem to be objects which may have indeed come from the temple. They were not only parts of a limestone cornice (Fig. 17) dated to the late Hellenistic period and fragments of vividly painted wall plaster, ${ }^{27}$ but also a part of a life-sized terracotta mask (Fig. 18) and some stone objects such as a fragment of a limestone bowl and possibly a part of a miniature limestone altar. The exploration to the south of the entrance has been stopped at a depth of $25.99 \mathrm{~m}$ asl, but it is planned to investigate deeper layers and expand the trench during the future field seasons.

\section{UNDERGROUND CHAMBERS 5, 6 AND 7}

In 2011, Balandier invited Jean-Claude Bessac to make an inventory and an architectural study of the underground chambers attested at the site. Bessac recorded at least fourteen chambers and was able to determine that six of them were carved during quarrying activities in the Hellenistic period, and later reshaped and reused for other purposes. ${ }^{28}$ Seven of them

\footnotetext{
${ }^{26}$ First discussed in: Młynarczyk 2020: 66, Pl. 3:3.

27 The study of architectural and painted decoration is the responsibility of Monika Rekowska.

${ }^{28}$ The results of Bessac's studies will be published in the first volume of the series dedicated to the presentation of the works of the French archaeological Mission at Paphos. For a first synthesis of this research, see: Bessac 2016: 111-116 and Balandier 2015: 168-171.
} 


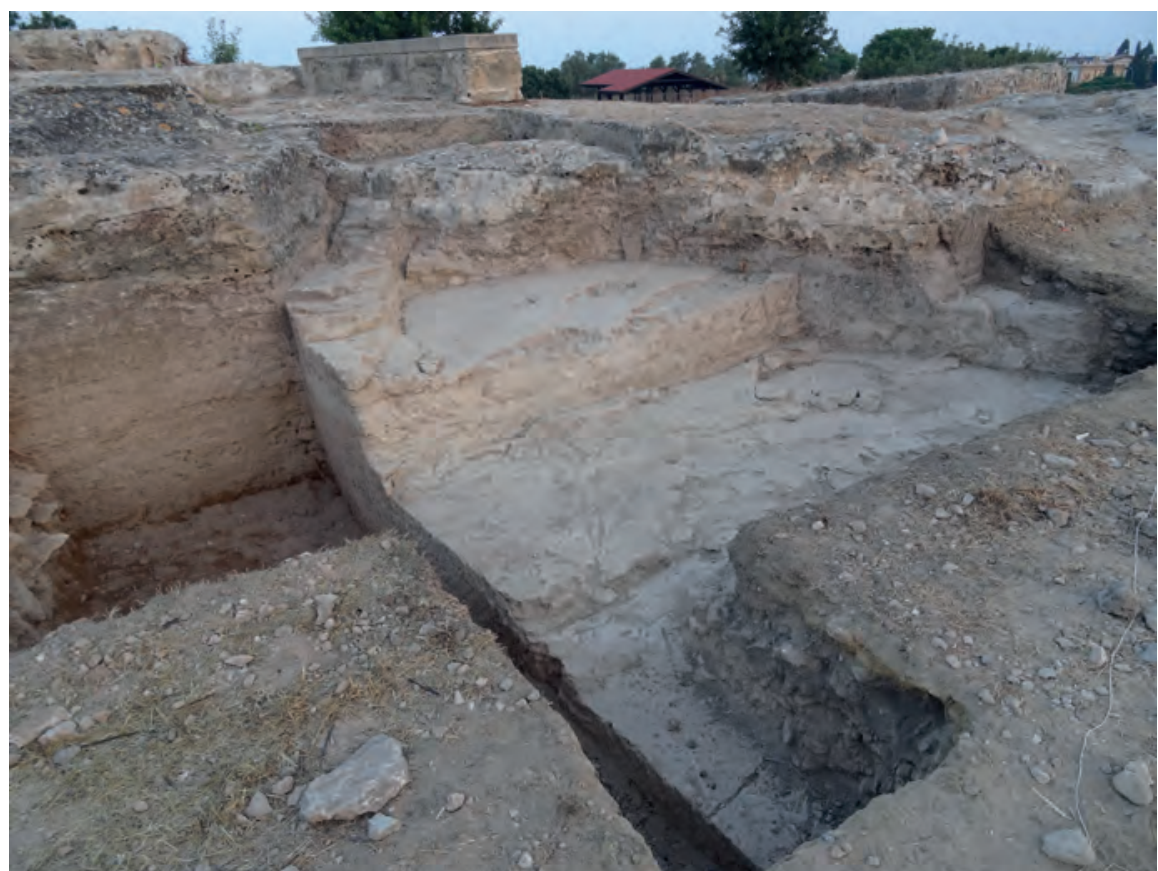

16. Trench VII: entrance to the north-eastern corner of the temple platform, with a step and a curved parapet on the southern side as well as a ramp below; view to the west (Phot. J. Młynarczyk).

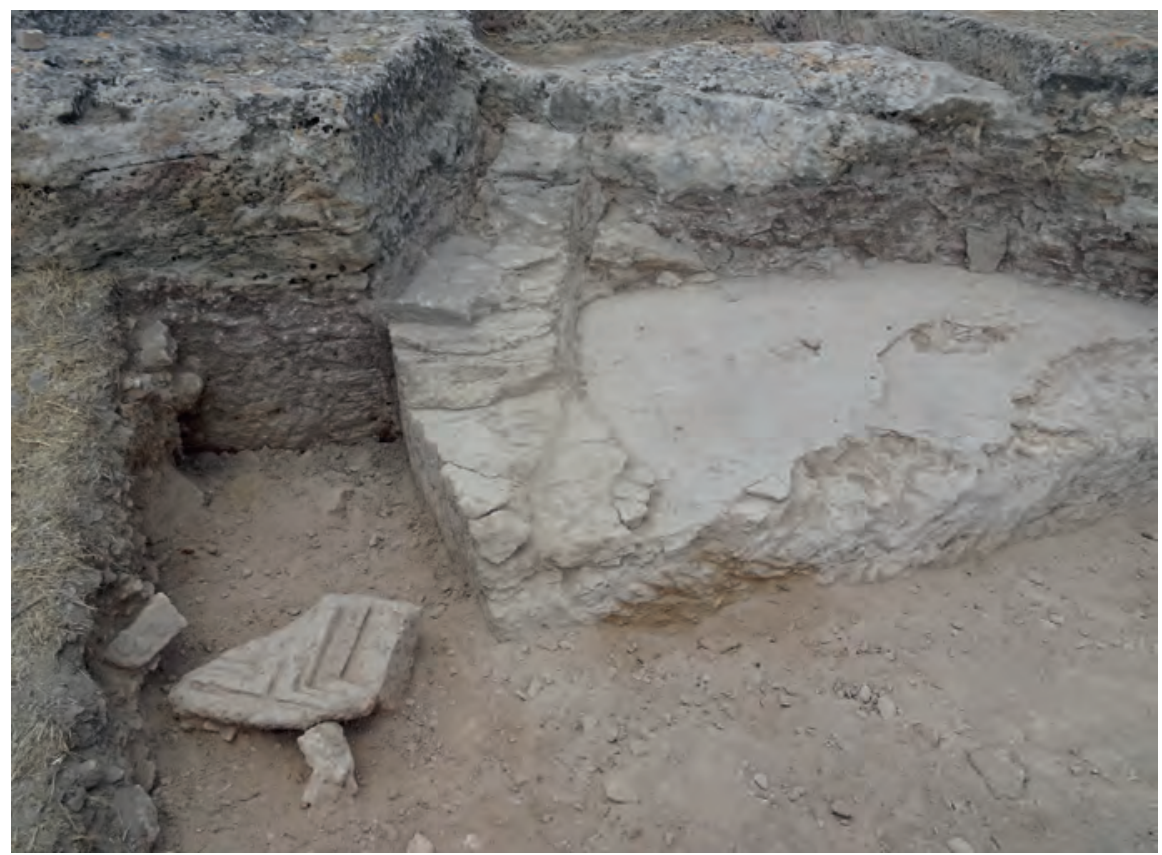

17. Trench VII: fragment of a limestone cornice by the step with curved parapet; view to the west (Phot. M. Rekowska). 


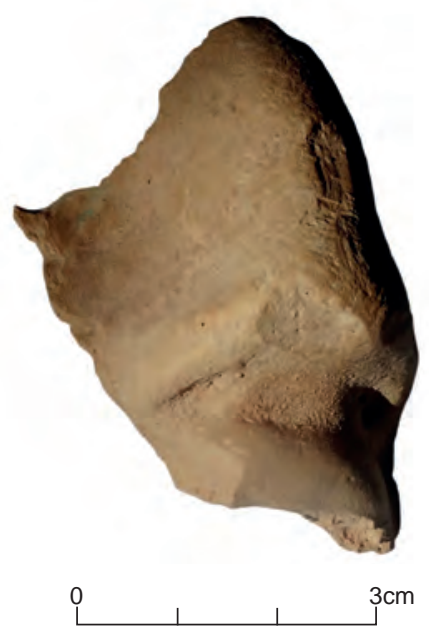

18. Trench VII: fragment of a life-size terracotta mask (Phot. J. Młynarczyk).

seem to have been used for cultic purposes in Hellenistic or Roman times. ${ }^{29}$ In order to understand their function and chronology, exploration of these chambers was initiated. In 2019, we decided to open two trenches in two interconnected chambers (Espaces 5-6 according to the Bessac's inventory; Fig. 19), situated c. 35m to the north-west from the temple platform (Fig. 1). ${ }^{30}$

Chamber 6 is trapezoidal in shape, elongated on a north-south axis, measuring c. 13m by $4.30 \mathrm{~m}$ at the ground level. After cleaning of the present-day surface of the whole chamber (Fig. 20), a trench was opened in the south-east corner. The first layer contained some stones and very few artefacts of mixed chronology and character, including modern objects, as well as two medieval glazed sherds and a human vertebra. In the south-east corner of the trench, a pit, possibly a post hole, filled with stones and surrounded by bones and big sherds was uncovered. Other bones were found at the foot of the southern wall in a more sandy layer. In the north-east corner of the trench some stones, joint by an earth mortar, were brought to light. The upper layer contained a horizontal stone, while the lower layer - vertical ones. It is very probable that this chamber was used as a cultic place by the Christians in the Byzantine or/and Frankish period. Hopefully, continuation of the research in subsequent excavation seasons will help us to determine more precisely the chronology of the use of this chamber.

Chamber 5 is slightly smaller than Chamber 6, and more rectangular in shape, measuring c. $11.50 \mathrm{~m}$ by $4.30 \mathrm{~m}$ (Fig. 21). A rocky semi-circular basin was carved in the western wall, $0.50 \mathrm{~m}$ above the modern level. Less than one meter to the south of this cavity there is a square recess, $0.10 \mathrm{~m}$ deep, c. $1.90 \mathrm{~m}$ above the present-day level. About $1 \mathrm{~m}$ to the south, a niche

\footnotetext{
${ }^{29}$ Balandier 2015: 171-178.

${ }^{30}$ Mentioned already in: Młynarczyk 2020: 69.
} 


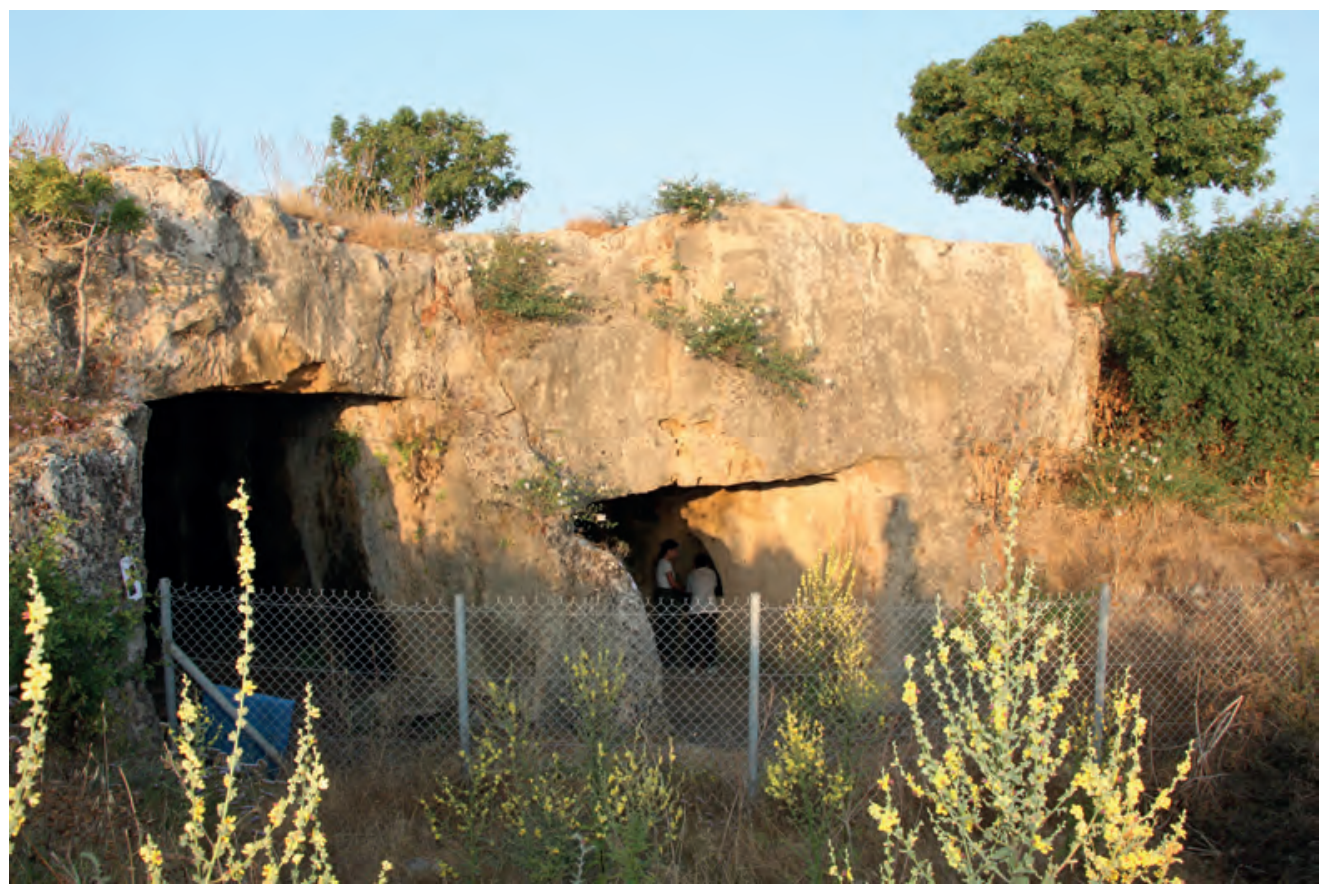

19. Entrances to underground Chambers 6 and 5; view to the south-west (Phot. C. Balandier).

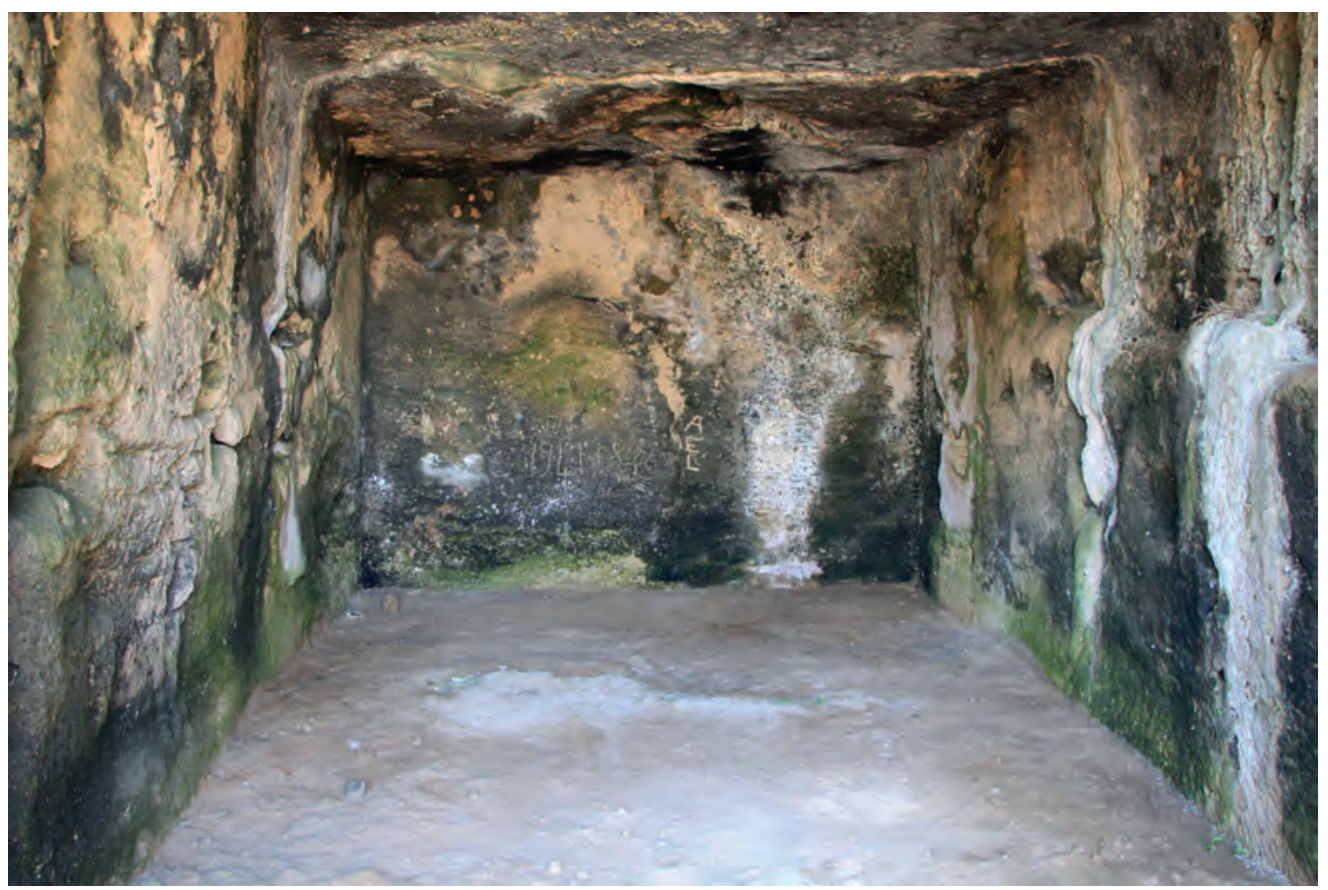

20. Chamber 6 after surface cleaning, and before excavation; view to the south (Phot. E. Chabert). 


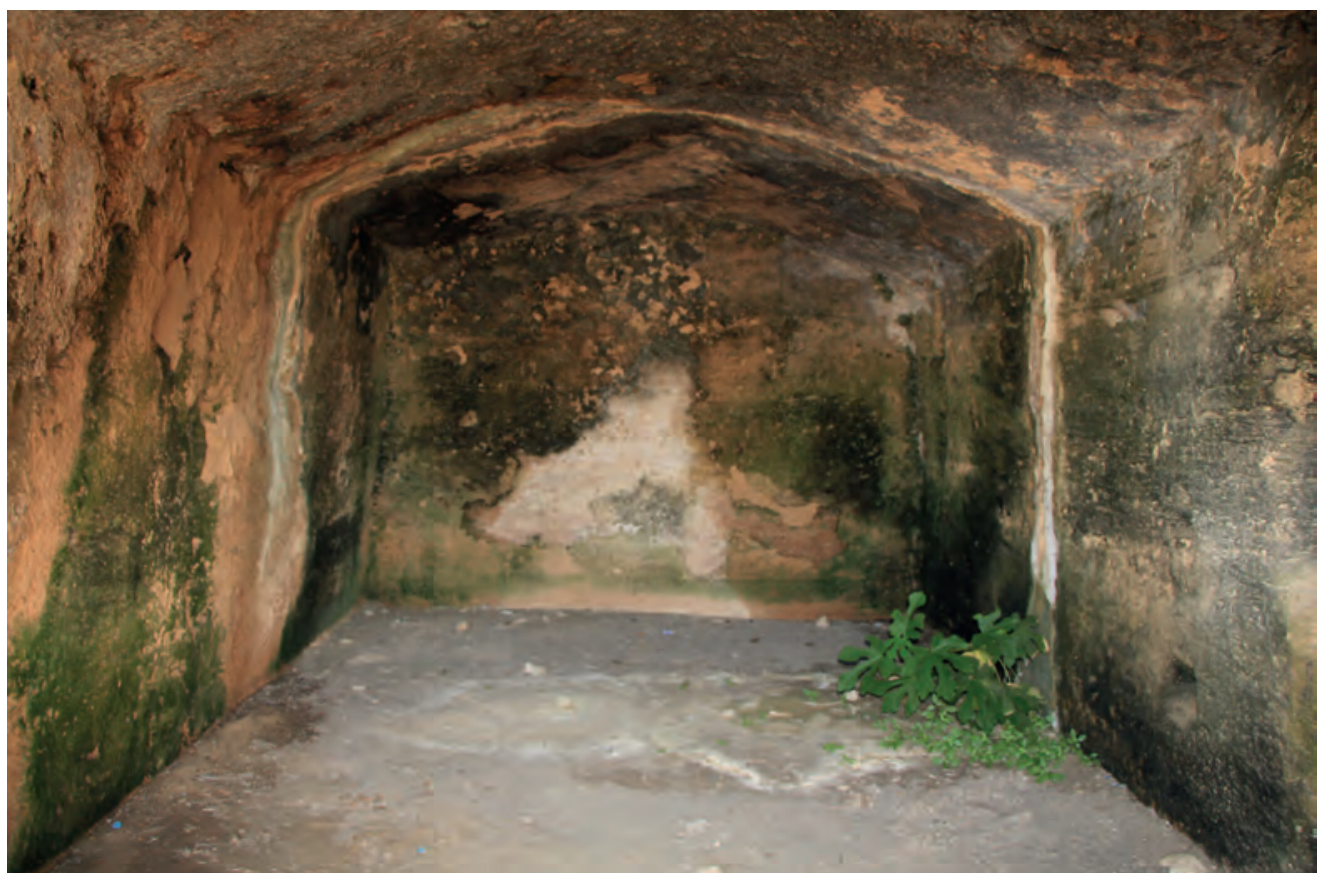

21. Chamber 5 before the excavation; view to the south (Phot. E. Chabert).

was carved in the wall. A trench was opened in the south-west corner of the chamber, later on extended to the width of the chamber. Under the present-day surface level, a very thick layer of rubble stones and chips was excavated down almost to the bedrock (Fig. 22). The bedrock itself bears traces of quarrying activities. It was covered by a thin layer of clay, possibly original floor, and then by a thick fill of rubble stones containing some artefacts, mostly pottery. Among them, there were not only sherds, but also complete lids and cups, as well as a lamp with burning traces and two fragments of terracotta figurines. Even if the ceramic assemblage has not been studied yet, it is clear that all these objects belong to a later part of the Hellenistic period, i.e. the second into first centuries BC. Moreover, the presence of cooking vessels with lids (Fig. 23) and a handle of a portable brazier of an Aegean origin, the latter dated to $c$. mid-second century BC (Fig. 24) ${ }^{31}$ suggests that the chamber may have been a place of preparing or serving food, presumably in connection with ritual banqueting.

To the south of Chambers 5-6, an another one was identified (Espace 7 in Bessac's inventory). In this case, the roof had collapsed but an exedra is preserved, equipped with three niches while the bedrock is decorated by a carved shell. ${ }^{32}$ Some remains of painted wall

\footnotetext{
${ }^{31}$ For a close parallel, see: Didelot 1998: Fig. 9.

32 Bessac 2016: 114, Fig. 10; Balandier 2012: 162-163, Fig. 13; 2015: 168-170, Fig. 4.
} 


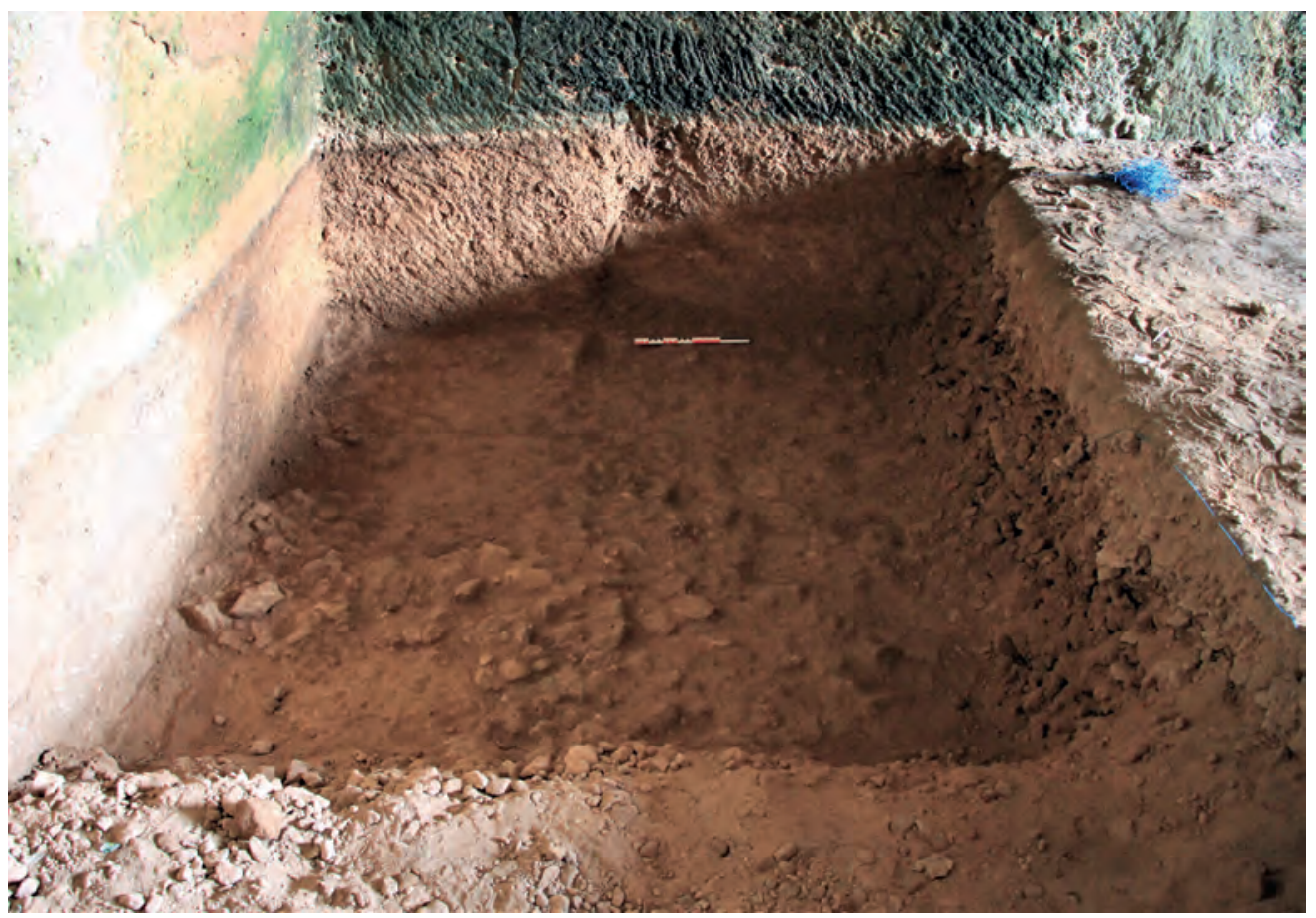

22. Chamber 5: fill of rubble stones above the bedrock; view to the west (Phot. C. Balandier).

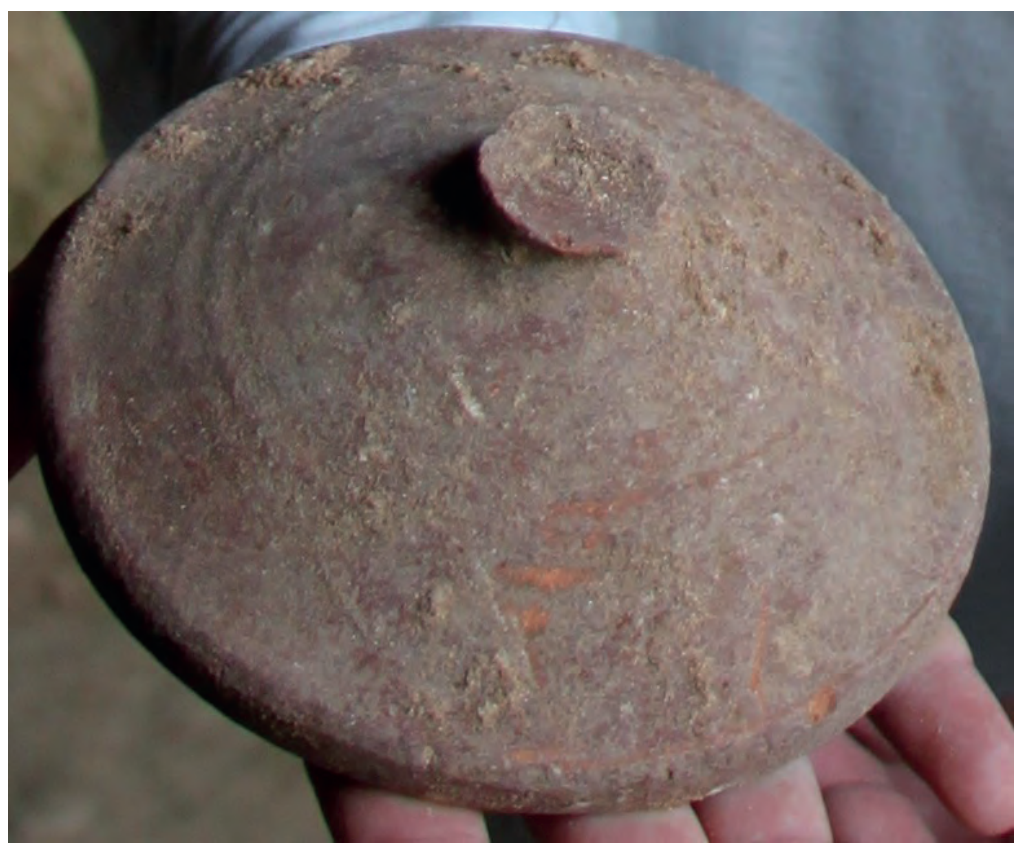

23. Chamber 5: one of the Hellenistic cooking-ware lids (Phot. C. Balandier). 


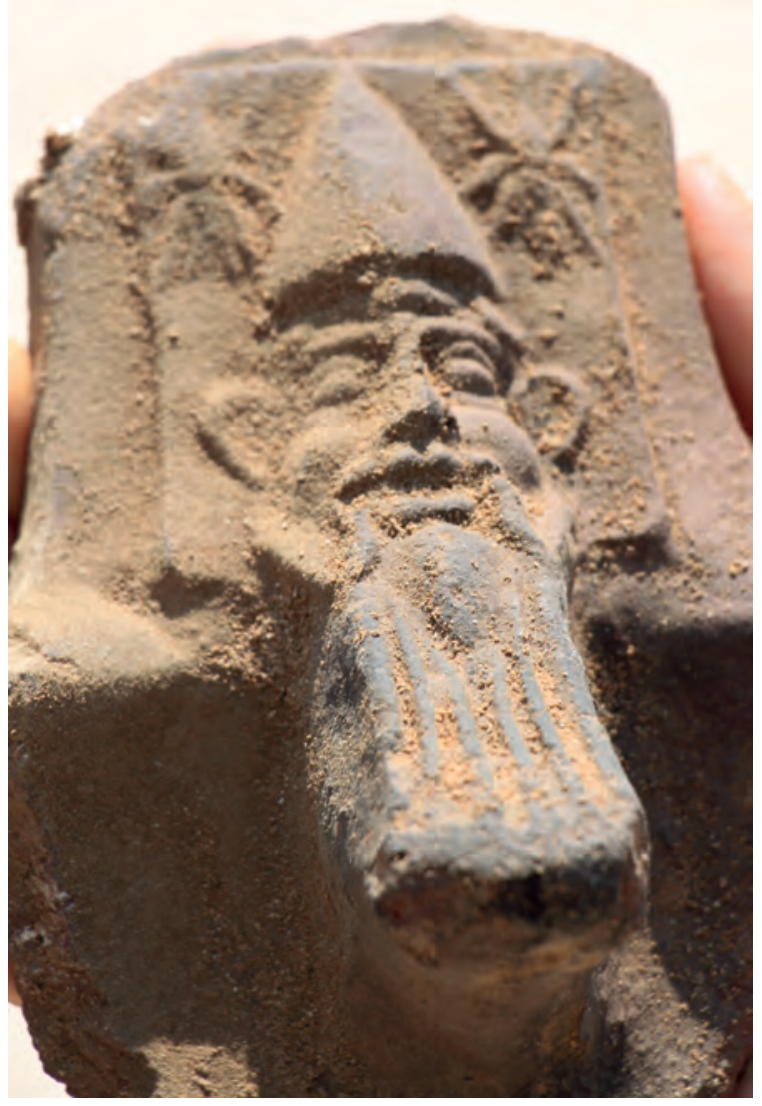

24. Chamber 5: handle of a Hellenistic brazier with a bearded male head in pilos, flanked by winged thunderbolts (Phot. C. Balandier).

decoration can be still seen in this chamber. Generally, it is situated very close to the temple, being just few meters below the western end of the platform. ${ }^{33}$

\section{CONCLUSIONS}

Before presenting our current conclusions about the temple, let us resume the historical phases of the usage of the site, starting with the more recent periods. The medieval architectural presence has been strongly attested in Trench IV and probably in underground Chamber 6 as well, while other trenches yielded just some medieval potsherds in the uppermost (humus) layers only.

The late Roman/Byzantine architectural remains have been definitely recorded only in Trench IV, even if it is still difficult to interpret them in detail. To the Byzantine period

${ }^{33}$ The shell carved in the bedrock in the bottom of the exedra could be perhaps linked to the cult of Aphrodite but also that of Sarapis or Isis, often linked to the Ptolemaic dynasty; cf. Balandier 2015: 174-177. 
doubtlessly belong the two burials in the forecourt of the temple, one child's burial in Trench I, two infant burials in Trench II and, apparently the three graves in Trench III, although in these very last cases, a Medieval date cannot be excluded. The presence of the graveyard could have been related to a small church, which - as suggested above - seems to have been situated in the central part of the ancient naos.

As for the Hellenistic to early Roman phase, it should be noted that the fills in Trenches I, III and V had been completed by about the mid-second century AD. Of the same date may have been also remains from the south-western part of Trench IV. Also, the destruction or, possibly, abandonment of the temple should be dated to the first half of the second century $\mathrm{AD}$, judging from the material recovered in Trench VII, at the temple entryway.

In terms of the sanctuary arrangement, the most important results were the discovery of the rock-cut altar with a libation or purification basin as well as the location of the entryway into the temple at the corner of the courtyard. Both these elements testify to the origin of the sanctuary outline in the indigenous tradition of the Cypriot religious architecture. ${ }^{34}$

Moreover, other features in the close vicinity of the temple platform point to a ceremonial character of the area. Among them are several rock-cut underground chambers such as Chambers 5, 6 and 7, clearly destined for some ritual activities, unspecified, however, for the moment. In this context, it should be also stressed that in the distance from the naos of only about $90 \mathrm{~m}$ as the crow flies there was the Hellenistic-period triclinium, doubtlessly of a cultic character, judging from the symbolism of the mosaic representation. A rescue excavation made in May 2015 by the French mission in collaboration with the Museum of Paphos showed that the triclinium belonged to a large building extending both to the south and the north of it. This Hellenistic building, supplied with water by terracotta pipes, was partly destroyed in Roman times, when new channels and a water tank were arranged to the south of the triclinium..$^{35}$ The ceramics, still to be comprehensively studied, seem to date the terracotta water pipes to the second century $\mathrm{BC}$, but they also include examples of Attic pieces of the late fourth century BC, while the triclinium mosaic itself has been dated to the third/second century BC by Anne-Marie Guimier-Sorbets. ${ }^{36}$

One of the underground chambers situated some $10-15 \mathrm{~m}$ to the south of the triclinium, being part of the complex (Espace 8 according to Bessac's inventory) extending under the triclinium and southwards, contains an enormous amount of late Hellenistic (second

${ }^{34}$ Młynarczyk 2020: 67-68.

35 Balandier 2015: 173; 2017: 229-230, Fig. 15. Results of the salvage excavations in the area were presented at the second 'Nea Paphos Symposium' in Paphos in October 2017 in a joint lecture given by Eustathios Rapotu, Margarita Kouali and Claire Balandier. The results of the research in the triclinium area will be presented in a single paper in the forthcoming proceedings of the conference (publication in preparation, edited by C. Balandier, D. Michaelides and E. Raptou, Nea Paphos and Western Cyprus. Proceedings of the 2nd international symposium on Paphos held at Paphos, 11-15 October 2017, organised by the Department of Antiquities of Cyprus, the University of Avignon and the University of Cyprus, " Mémoires », Ausonius Éditions, Bordeaux).

${ }^{36}$ Guimier-Sorbets 2009: 148-152. 
to first century BC) pottery. ${ }^{37}$ Quite probably, this pottery deposit may be connected with activities taking place at the above-mentioned triclinium. To check this possibility, it is essential to examine the area directly overlying the chamber in question.

In conclusion, the two archaeological seasons (2018-2019) of collaboration on the study of the southern area of the top of Fabrika hill brought new significant results regarding the nature of the site. It seems that during the Hellenistic and early Roman periods this part of Fabrika hill was a unique sacred zone. But which deities were worshipped there? Was it Aphrodite, as we proposed elsewhere, and as suggested by both the local topography and the find spots of some relevant inscriptions ${ }^{38}$ Or possibly these were some GraecoEgyptian deities, like Sarapis and Isis, or maybe one of the Ptolemaic queens assimilated to Aphrodite? ${ }^{39}$ We hope that the next seasons of excavations will help to answer this question and shed light on the connection between the temple, the underground chambers and the building with the triclinium, as well as on their chronology.

\section{Acknowledgements}

The archaeological research on the Fabrika-south in the framework of the joint project is financed by the National Science Centre, grant Harmonia 8: 2016/22/M/HS3/0035 and by the French Ministry of Europe and Foreign Affairs. It also benefited of an annual support from Avignon Université and from the CNRS Research Unit 8210 Anthropologie et Histoire des Mondes Anciens.We want to warmly thank Eustathios Raptou and Margarita Kouali, as well as Neoptolemos Demetriou and Andreas Michaelides (Archaeological Museum of the Paphos District) for their assistance. We are very grateful to the restorers of the Department of Antiquities in Nicosia who cleaned and preserved the coins (which have now been sent to the Paphos District Museum) as well as Anne Destrooper-Georgiades who studied them. We are also grateful to Grigoria Ioannou who accepted to study the skeletons. Unfortunately, she got permission only a few days before the lock down following the deteriorating health situation in March 2020. We hope she will be able to continue the study as soon as possible.

\section{References}

Balandier, C. 2012: Du nouveau sur la capitale hellénistique et romaine de Chypre : premiers résultats de la Mission archéologique française à Paphos [MafaP] (2008-2012), DHA 38/2, 151-164

Balandier, C. 2015: Lieux de cultes sur et sous la colline de Fabrika. Soubassement de temple et autres sanctuaires rupestres ptolémaïques et romains de Néa Paphos, CCEC 45, 161-180

\footnotetext{
37 Młynarczyk 2020: 70, Pl. 5:2.

38 Młynarczyk 1985; 1990; 2015; 2020: 62, 71-72; Balandier 2015: 165-166.

39 Balandier 2015:178.
} 
Balandier, C. 2017: Nea Paphos (Chypre). De la fondation hellénistique au développement de la ville romaine : derniers résultats de la Mission archéologique française à Paphos [MafaP] 2014-2017, DHA 43/2, 217-231

Balandier, C., Morvillez, E. 2009: Nouvelles recherches archéologiques à Paphos : premiers résultats de la mission française sur la colline de Fabrika (2008-2009), CCEC 39, 425-447

Barker, C. 2015: Some initial observations on a building excavated on Fabrika in Nea Paphos in Cyprus by the Australian Archaeological Mission, SAAC 19, 169-189

Barker, C. 2016: The Theatre Precinct of Nea Paphos (Fabrika): Recent Excavations by the Australian Mission, [in:] Balandier, C. (Ed.), Nea Paphos. Fondation et développement urbanistique d'une ville chypriote de l'Antiquité à nos jours. Études archéologiques, historiques et patrimoniales, Actes du $1^{\text {er }}$ Colloque international sur Paphos, Avignon 30, 31 octobre et $1^{\text {er }}$ novembre 2012, Ausonius Mémoires 34, Bordeaux, 91-104

Bessac, J.-C. 2016: Les aspects techniques des aménagements rupestres de Paphos, [in:] Balandier, C. (Ed.), Nea Paphos. Fondation et développement urbanistique d'une ville chypriote de l'Antiquité à nos jours. Études archéologiques, historiques et patrimoniales, Actes du $1^{\text {er }}$ Colloque international sur Paphos, Avignon 30, 31 octobre et $1^{\text {er }}$ novembre 2012, Ausonius Mémoires 34, Bordeaux, 105-120

Daszewski, W.A. 1978: Dawna stolica Cypru w świetle polskich badań archeologicznych, Meander XXIII/4, 171-187

Didelot, O. 1998: Réchauds hellénistiques du Musée gréco-romain d’Alexandrie : importations et productions locales, [in:] Empereur, J.-Y. (Ed.), Commerce et artisanat dans l'Alexandrie hellénistique et romaine. Actes du Colloque d'Athènes organisée par le CNRS, le Laboratoire de céramologie de Lyon et l’École française d’Athènes, 11-12 décembre 1988, BCH-Suppl. 33, Athènes-Paris, 275-306

Guimier-Sorbets, A.-M. 2009: L’iconographie des mosaïques hellénistiques de Chypre, CCEC 39, 141-152

Hayes, J.W. 1972: Late Roman Pottery, London

Hermary, A., Mertens, J.R. 2015: The Cesnola Collection of Cypriot Art. Stone Sculpture, New York

Karageorghis, V. 1988: Chronique des fouilles et découvertes archéologiques à Chypre en 1987, BCH 112/2, 793-855

Młynarczyk, J. 1985: Remarks on the temple of Aphrodite Paphia in Nea Paphos in the Hellenistic period, RDAC 1985, 286-292

Młynarczyk, J. 1990: Nea Paphos in the Hellenistic Period, Nea Paphos III, Varsovie Młynarczyk, J. 2015: Moving to a new place: the cult of Paphia Aphrodite in Hellenistic Nea Paphos, CCEC 45, 79-86

Młynarczyk, J. 2020: New research in the sacred zone of the Fabrika hill in Nea Paphos, Cyprus, SAAC 24, 59-76 
PaphosTheatre: www.paphostheatre.org (accessed February 2, 2021)

Peacock, D.P.S., Williams, D.F. 1986: Amphorae and the Roman economy. An introductory guide, London-New York

Wright, G.R.H. 1992: Ancient Building in Cyprus, Leiden-New York-Köln 


\section{ÉTUDES et TRAVAUX XXXIV / 2021}
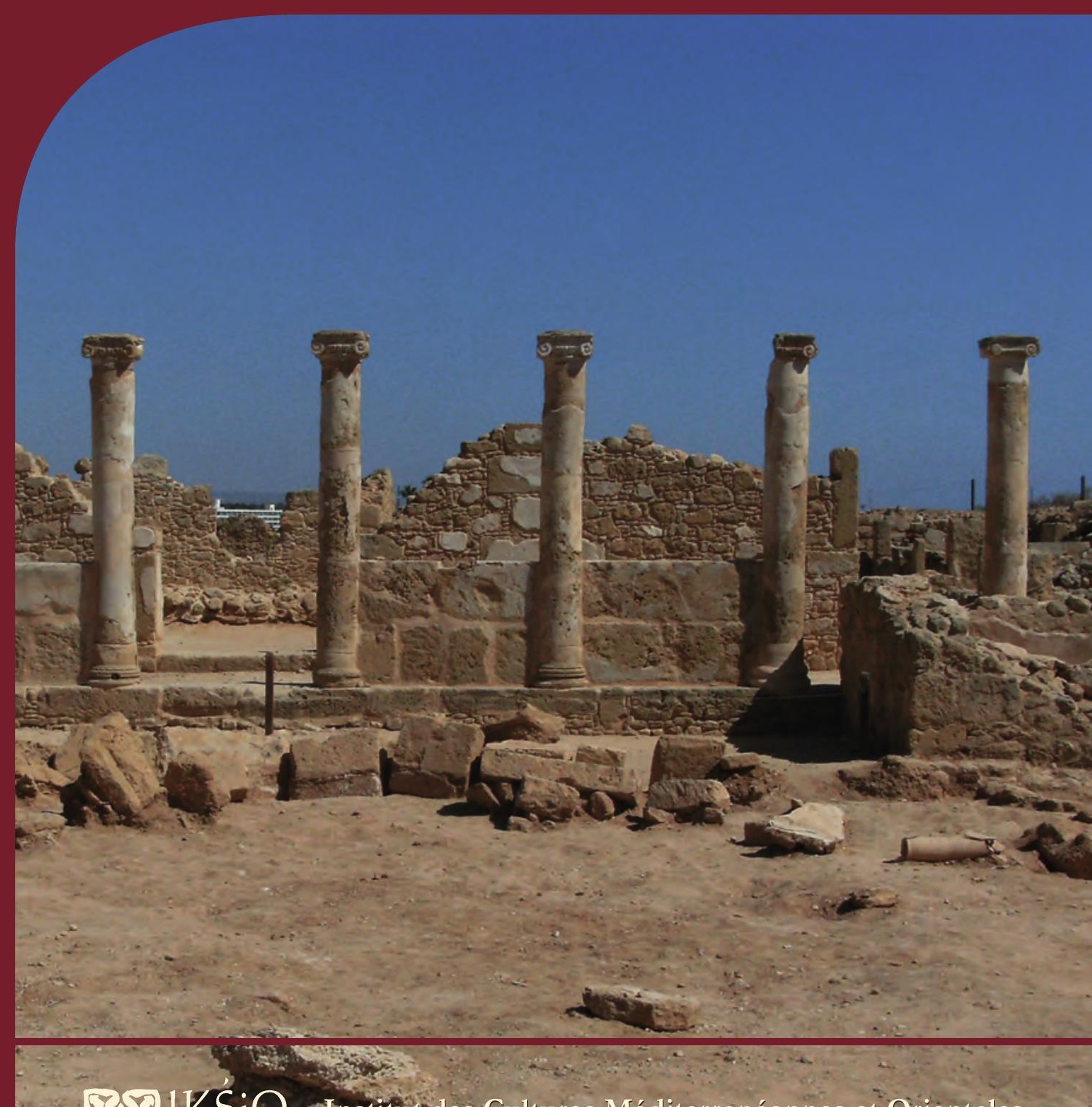

W $92 \mathrm{HKSiO}$ Institut des Cultures Méditerranéennes et Orientales

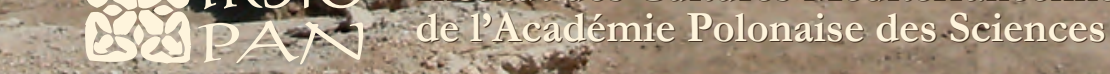

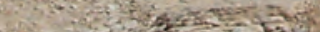

Q 
COMITÉ DE RÉDACTION SCIENTIFIQUE

Maciej Makowski - rédacteur en chef

Jadwiga Iwaszczuk - rédacteur

Katarzyna Kapiec - secrétaire de la rédaction

Henryk Meyza - rédacteur thématique du volume

CONSEIL SCIENTIFIQUE DU JOURNAL

M. Kobusiewicz (IAE PAN, Warszawa)

E. Laskowska-Kusztal (IMOC PAS, Warszawa)

D. Michaelides (University of Cyprus, Nicosia)

J.Ch. Moretti (IRAA-MOM, Université de Lyon 2/CNRS)

D. Raue (Ägyptisches Museum der Universität Leipzig)

P. Reynolds (ICREA, España)

D. Welsby (British Museum, London)

COMITÉ SCIENTIFIQUE DE LECTURE

la liste des membres du comité est accessible en ligne sur

http://www.etudesettravaux.iksiopan.pl

RÉDACTION TECHNIQUE

Marta Kaczanowicz

REVUE DES TEXTES EN ANGLAIS

Jo Harper 
ÉTUDES et TRAVAUX XXXIV 
INSTYTUT KULTUR ŚRÓDZIEMNOMORSKICH I ORIENTALNYCH POLSKIEJ AKADEMII NAUK

\title{
STUDIA i PRACE
}

\section{XXXIV}

\author{
GoIKSiO \\ QSO PAN \\ WARSZAWA \\ 2021
}


INSTITUT DES CULTURES MÉDITERRANÉENNES ET ORIENTALES DE L’ACADÉMIE POLONAISE DES SCIENCES

\section{ÉTUDES et TRAVAUX}

XXXIV

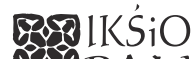

EOSPAN

VARSOVIE

2021 
Publication scientifique financée dans le cadre du programme du Ministre de la Science et de l’Éducation Supérieure

« Programme National de Développement de l’Humanistique » pour les années 2016-2021 (projet no 3bH 150099 83)

\title{
(1) NARODOWY PROGRAM ROZWOJU HUMANISTYKI
}

\author{
Copyright $(C)$ \\ Instytut Kultur Śródziemnomorskich i Orientalnych PAN \\ et les Auteurs \\ Warszawa 2021
}

ISSN 2084-6762

(jusqu'en 2011 : 0079-3566)

e-ISSN 2449-9579
Version première en papier, imprimée en Pologne - 150 copies
Version électronique accessible sur
http://www.etudesettravaux.iksiopan.pl

Édition: Polskie Towarzystwo Historyczne et Wydawnictwo Neriton, Warszawa

Conception générale de la couverture : J. Iwaszczuk

Photographie de couverture : Phot. A. Brzozowska-Jawornicka

(Le portique ionique est, péristyle de la Maison « hellénistique », Nea Paphos) 


\section{Table des matières}

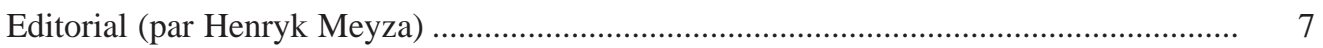

Marta BaJTLER

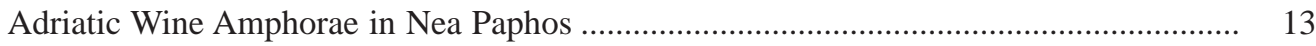

Claire Balandier, Jolanta MlynarczyK

The Temple and Its Surroundings on Fabrika Hill, Paphos: Preliminary Results

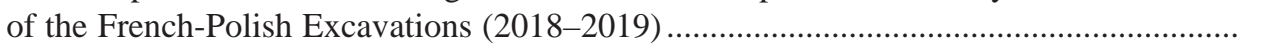

Grażyna BĄKowska-Czerner, Rafal CzERner

The Shell Motif in the Culture and Architecture of the Ancient Town of Marina el-Alamein in Egyp

AleKsandra BrzozowsKa-JaWornicKa

'Hellenistic' House in Nea Paphos, Cyprus - A First Summary of Its Architecture.

AleKsandra BrzozowsKa-JaWORnicKA, AnNa KuBICKA-SowińsKa

In Search of the Module in the Architectural Design of the 'Hellenistic'

House in Nea Paphos, Cyprus

RoKsana HaJduga

Kushite Stamp Impressions from Selib 2, Sudan

ERSIN HusSEIN

Mapping Metal Rich Roman Cyprus: The Case for Object-Centred Approaches

BARBARA LICHOCKA

Villa of Theseus at Nea Paphos (Cyprus). Fourth-Early Fifth Century Numismatic

Evidence for Architectural Transformations and Seismic Events

VASiliki Lysandrou, Demetrios Michaelides

Wall Paintings in Ancient Cyprus: The Hellenistic and Roman Tombs of Paphos

and Its Region

ADAM ŁAJTAR

A Weight of Seleucia in Pieria in Nea Paphos

Diana MroczeK

Ancient Portrait Busts of Marcus Aurelius in the National Museum in Poznań 
Brandon R. Olson, R. Scott Moore, Thomas Landvatter, Justin Stephens

Pyla-Vigla: A Case Study Assessing the Imperial Strategies of the Hellenistic

Diadochoi in Cyprus

Patrizio Pensabene, Eleonora Gasparini

Colonnaded Hall in Kourion: How the Oecus Corinthius Was Interpreted in the Roman

Houses of Cyprus

Monika Rekowska, Demetrios Michaelides, Skevi Christodoulou, JAKUB KANISZEWSKI

Adopting Roman Habits - The Baths in the House of Orpheus in Nea Paphos

as a 'Troublesome' Case Study?

MARCIN M. ROMANIUK

Terracotta Pipelines at Maloutena: Remarks on the Water System in the

Residential District of Ancient Nea Paphos, Cyprus

363

ABRÉVIATIONS

407 